\title{
On the Urinary Output of 17-Ketosteroids, 17-Hydroxycorticosteroids, Uropepsin and Gonadotrophin, in Rabbits Born of Ancestors Fed with Thyradin or Thyroidectomized for Successive Generations. \\ By
}

\author{
Junji TSUJITA \\ Pathological Institute, Faculty of Medicine, Kyoto University (Director: Prof. Dr. K. Okamoto)
}

A series of studies has been carried out for several years in Prof. Okamoto's laboratory on the morphological and pathophysiological changes occuring in the offspring of rabbits born of ancestors either fed with thyradin or thyroidectomized for several successive generations. These are the conclusions :

The offspring of rabbits descended from ancestors fed with thyradin for successive generations showed a picture of thyroid hyperfunction which has been aggravated as the generation went down from $\mathrm{F}_{1}$ to $\mathrm{F}_{6}$. Hyperthyroidism was present especially in $\mathrm{F}_{5}$ and $\mathrm{F}_{6}$ rabbits. On the other hand in the offspring of rabbits born of ancestors which had been thyroidectomized, the function of the thyroid gland decreased progressively as the generation went down from $F_{1}$ to $F_{4}$.

The author of this paper studied the urinary output of 17-KS, fractions of 17-KS, 17-OHCS, uropepsin and gonadotrophin, of the rabbits mentioned above. The results obtained by comparing these rabbits with normal control rabbits and rabbits fed with thyradin or thyroidectomized are in summary as follows :

(1) The offspring of rabbits born of ancestors fed with thyradin for successive generations showed an increase in the amount of urinary 17-KS, fractions of 17-KS (VI, VII), 17-OHCS, uropepsin and gonadotrophin. Especially $F_{5}$ and $F_{6}$ rabbits showed an extreme increase in the amount of urinary steroids and gonadotrophin from the weaning period.

(2) The rabbits fed with thyradin showed an increase in the amount of urinary 17-KS, fractions of 17-KS (III, VI, VII), 17-OHCS, uropepsin and gonadotrophin at first, but dropped to subnormal output. That is, rabbits fed with thyradin differ from rabbits born of ancestors themselves fed with thyradin in the urinary output patterns of steroids and gonadotrophin.

(3) The offspring of rabbits born of ancestors thyroidectomized for several successive generations showed a decrease in the amount of urinary 17-KS, fractions of 17-KS (VI, VII), 17-OHCS, uropepsin and gonadotrophin.

(4) The thyroidectomized rabbits showed a decrease in the amount of 17-KS, fractions of 17-KS, (II, III, VI, VII), 17-OHCS, uropepsin and gonadotrophin.

The above mentioded results of the measurement of urinary steroids and gonadotrophin lead us to infer that there is some difference in the function of the adrenal cortex and the urinary output of pituitary gonadotrophin between the offspring of rabbits descended from thyroidectomized and rabbits themselve thyroidectomized. 


\title{
歴代甲状腺機能異常子孫ウサギの尿中 17-Keto-
}

\author{
steroids, 17-Hydroxycorticosteroids, ウロペプ \\ シン,ゴナドトロピンについて
}

宗都大学医学部病理学教空（指導 岡本耕造教授）

辻田純 二

目次

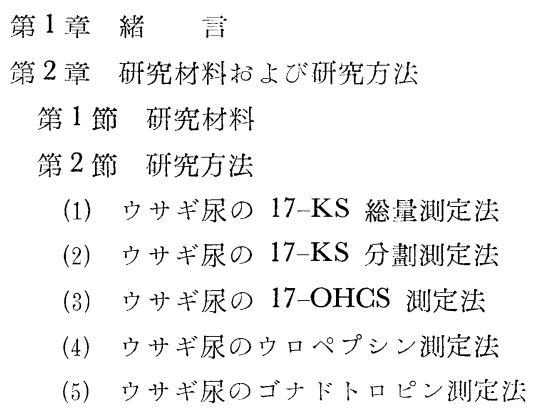

筈 3 测定成結

\begin{tabular}{|c|c|}
\hline 目 & 次 \\
\hline 第 1 章 緒 & 第 1 節 刘照正常ウサギ \\
\hline 第 2 章 研究材料打よび研究方法 & 第 2 節 歴代甲末投与子孫ウサギ \\
\hline 第 1 節 研究材料 & 節 3 節 歴代甲摘子孫ウサギ \\
\hline 第 2 節 研究方法 & 第 4 節 用末投与ウサギ \\
\hline （1）ウサギ尿の $17-\mathrm{KS}$ 総量測定法 & 第 5 節 甲摘ウサギ \\
\hline （2）ウサギ尿の 17-KS 分劃测定法 & 第 6 節 測定成績の絩棓的検定 \\
\hline (3) ウサギ尿の 17-OHCS 測定法 & 第 4 章 考 \\
\hline （4）ウサギ尿のウロペプシン測定法 & 第 5 章 総 \\
\hline (5) ウサギ尿のゴナドトロピン测定法 & 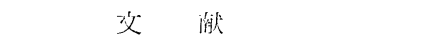 \\
\hline 籍 3 等 测定成縜 & \\
\hline
\end{tabular}

第 1 章 緒

甲状腺機能異常疾患すなわち甲状腺機能九進症わよび低下症（それぞれバセドウ氏病および粘液水腫をむ つて代表される）の発病に，遗伝的素因の関与することはすでに Bartels ${ }^{3}$ らによつて注意されている，バセ ドウ氏病，粘液水腫いずれも家系的に宮い発生をみることが最近注目され，Bernheim ら先天性粘液水朠 息者について詳細な研究調查を行ない，その両親に甲状腺機能異常が存在すること，およびその家系に㬰状

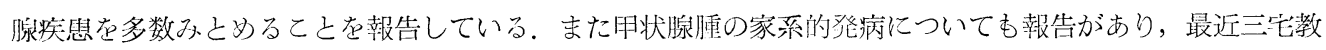

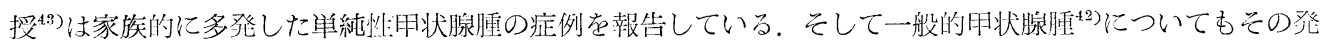
病に早にヨード掑取量などの問題によつては理解できない内的因子の存在在想定している。しかしこれらの

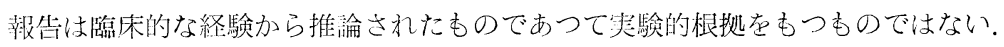

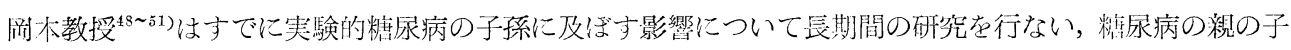

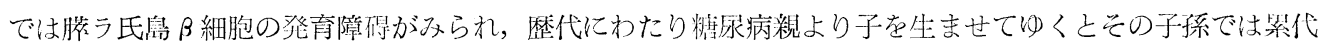

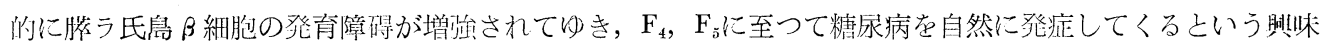

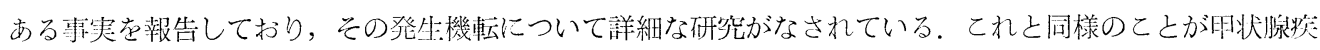
思についてもみられるのではなからうかとの考えより，同教授の教室では数年前よりウサギを用いて甲状脉

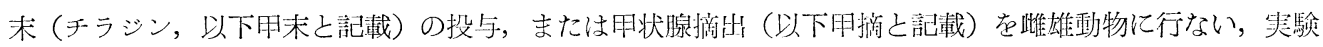

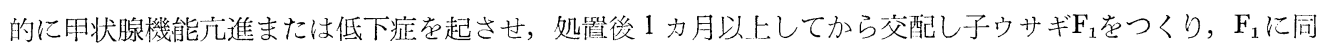
様の処置を行なつて孫ウサギ $\mathrm{F}_{2}$ をつくり，以後同様のことをくりかえして得た子孫りサギについて研究を行

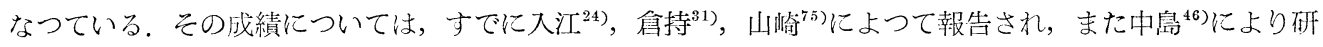
究されているところであるが，乙れら子孫ウサギの明状腺の組織計測学的所見，血清 PBI 值， I ${ }^{131}$ 掑取率，

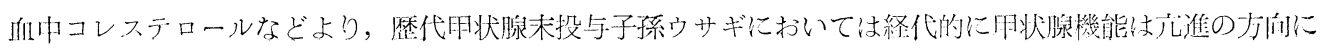


すすみ，一方歴代甲状腺摘出子孫ウサギでは経代的に甲状腺機能は低下のう问にすすむという注目すべき事 実が明らかにされている。 とくに甲未投与 $\mathrm{F}_{5}, \mathrm{~F}_{6}$ ウサギの大部分は機能充進像を示しているととがるとめら れるに至つた ${ }^{46,75)}$. 乙れら一連の実験成果は先天性甲状腺疾患の発症や, その先天性素因生成の一つの道者 暗示するもののように考元られ興味深い.

さて生体内分泌系は神経系之とすに有機的協同作用により生体を調節支配しており，その一つである甲状 腺の機能に異常をきたす時は，他の内分泌機能にも種々の変化をきたすととは当然と考光られる ${ }^{62,74)}$. との 変化について研究するとと注用状腺聅患の病熊生理の解明に重要な意義をむつ之考光られ，とくに下垂体副 腎系之甲状腺の相互関係については以前より多くの報告がある。すなわち，Engstrom ら ${ }^{12)}$ ，Kenigsberg ら ${ }^{28)}$.

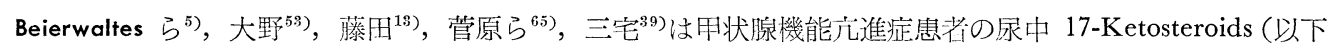

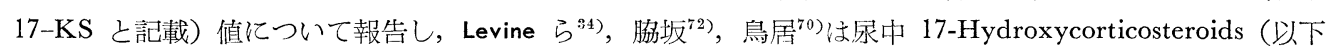
17-OHCS 之記載）值について報告している。をえれらによると，尿中 17-KS 注正常值または增加している ことああるが，おおむね減少しているというあのが多い，尿中 17-OHCS については䯩值を示すすのが多い， ウロペプシンについては，Gray ら ${ }^{18)}$ ，Vartio ${ }^{71}$ ，福住ら ${ }^{15)}$ は正常または增加しているととが多いとしている. つぎに脳下垂体前葉ホルモンの一つであるゴナドトロピンについては, Sadowski $ら^{61)}$, Guinet ${ }^{19)}$, Howell

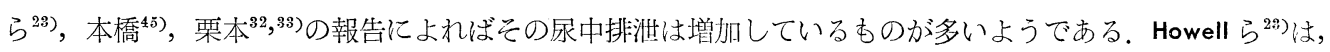
とくに 8 才のバセドウ氏病患者の尿中にゴナドトロピンが著明に增加していた例に注目している.

一方，甲状腺機能低下症では，尿中 17-KS，17-OHCS，ウロペプシンいずれす一致して低值を示すという

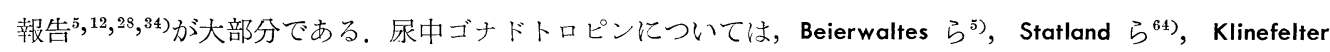
ら ${ }^{299}$ は正常值を示すすのが多いが，時に低值を示すという，以上の諸報告をみると人体の甲状腺機能異常疾 患之くにその機能准症においては必ずしも一致した成績は得られていないようである.

人体についての研究には明らかに限界があり，一歩進んだ検索は動物实験によらねば不可能である。すで に述べたように妇状腺疾患の発病に先天的素因が注目されており，しかむわが教室においては甲状腺疾患に 対する先天性素因を有するウサギが作製されている。したがつててのようなウサギについて種々の病態生理 学的検索を行なうことは，人体甲状腺疾患の病態生理ひいてはその本態の解明になんらかの寄与をなすので はなからうかと考えられる。乙こにおいて私はこれらウサギの下垂体副腎系の機能の追究を企図し，尿中 17-KS 総量ならびに分劃，17-OHCS，ウロペプシン，ゴナドトロピンの測定を行ない，その結果を正常ウ サギや正常ウサギに甲未を投与しまたは甲摘を行なつたさいに得られた成績と比較し，一定の成績を得たの でここに報告する次第である。

\section{第 2 章 研究材料および研究方法}

\section{第 1 節 研究材料}

\section{（1）対照正常ウサギ}

教室で妊娠分婏させて得た正常ウサギおよび生後日数の明らかな正常りサギを業者より購入して使用した。 そのうち，オス 5 例，メス 5 例，計10例について生後50日の㭃若時より成長とともにその推移を追究した。 生後 120 日以後のあのについては体重 $2 \sim 3.5 \mathrm{~kg}$ ののについてオス, メス 10例あて言十20例について測定した. 動物は教室の飼育室において他の実験動物之同一条件で飼育した。すなわち，カラスムギまたはオオムギ， ニンジン，オカラを自由に与えた。しかしキャベッ，サッマイモッ゙ルなど甲状腺腫誘発物質を含むと考えら

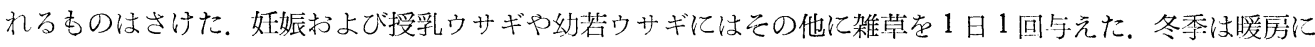
より室温を $10^{\circ} \mathrm{C}$ 以に保ち，夏季は通風に留意した，子ウサギは多く生れたときはあらかじめ用意したウバ ウサギに一部移して生後50日まで親およびウバウサギととるに飼育した。生後 50 日後には 1 匹づつ飼育箱に 入れて飼育した。

採尿時には動物の健康状態に注意し, 疾病その他異常所見のあるものはさけた。採尿は教室で作製した採 尿符を使用し，オカラなどの不純物の泿入在できるだけさけ，また採尿中はとくにりサギの健康状熊に注意 
した．採尿は自然の状態で行なうために動物を一定期間採尿箱に飼育し慣れて尿量が一定した時期に行なつ た，尿中のホルモンの変性を防ぐために尿は直ちに氷室に保存し，できるが゙り速かに測定操作在加光た。 夏否はとくに关の点に注意した。

\section{(2) 歴代甲末投与子孫 $F_{1}, F_{4}, F_{5}, F_{6}$ ウサギ}

この材料はつぎのようにして作られた，正常成熟オス，メスウサギに $30 \mathrm{mg} / \mathrm{kg}$ の本すなわちチラジンを

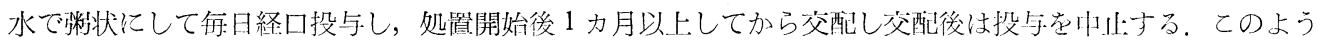

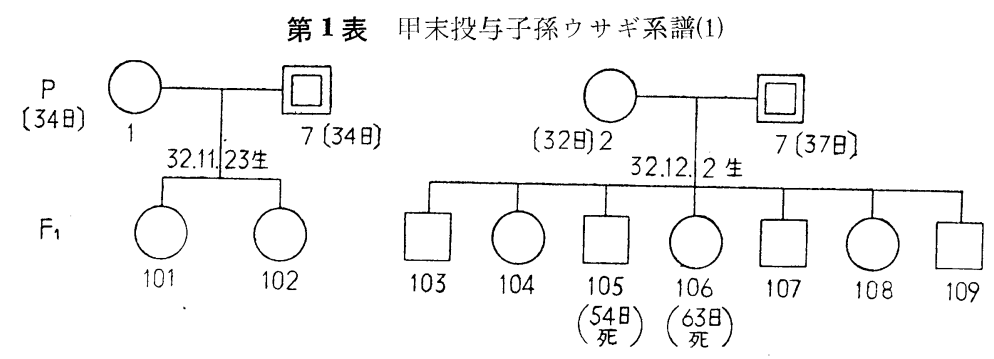

第 2 表 明末投与子孫ウサギ系譜(2)

(†),

F 30 (30) $309 \times 31.12$.2501 30 (30日)

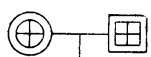

$F_{4}$
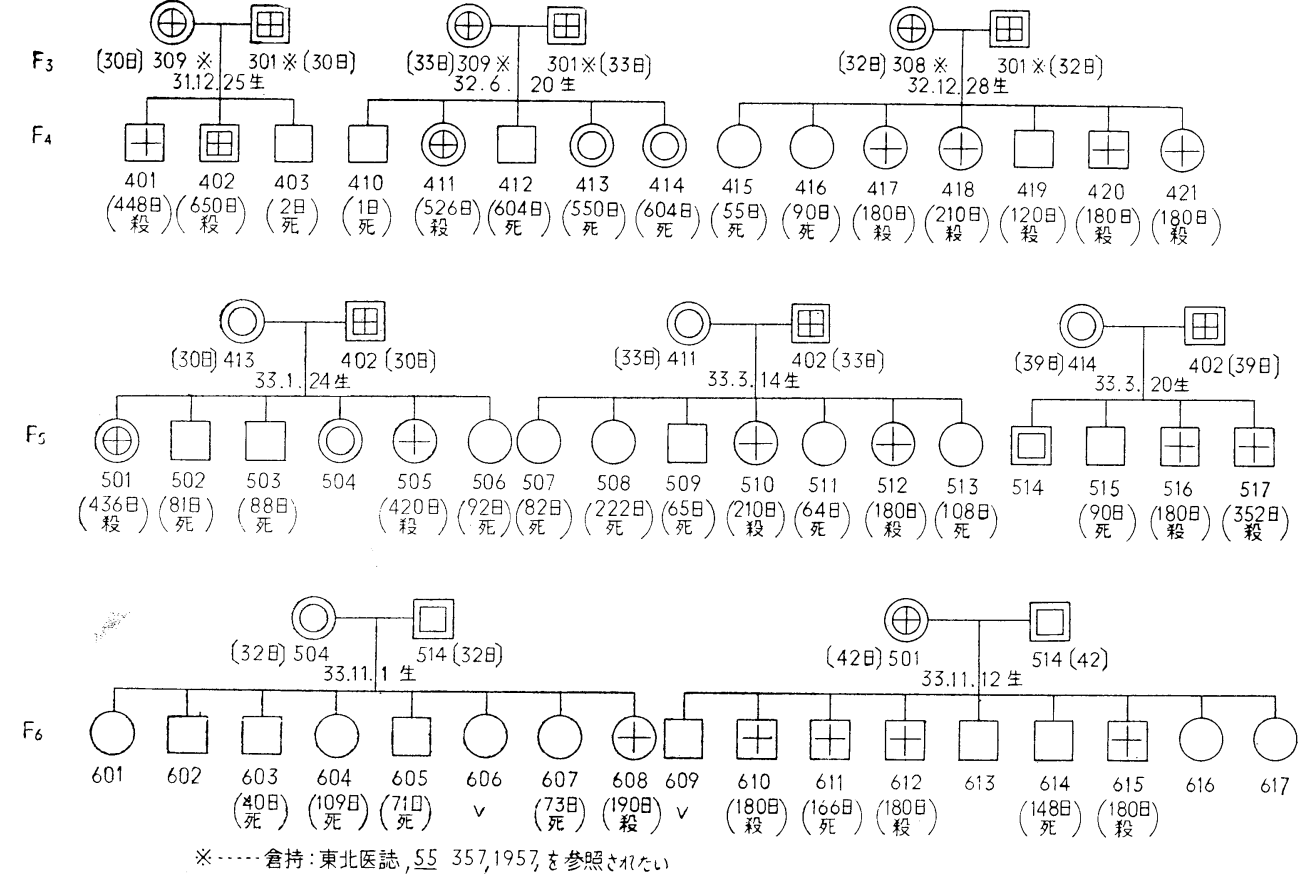

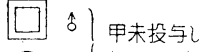

(O) 早)親红使用

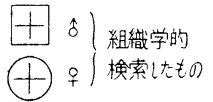

〔 〕内数字は交配までの甲未投与日数 


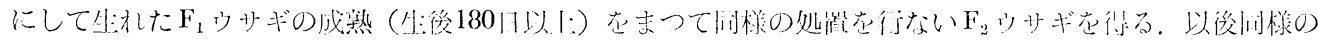

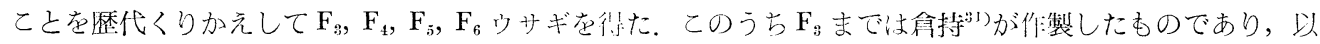

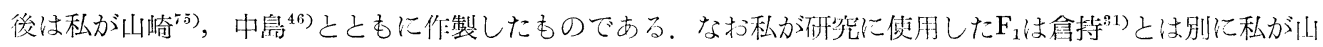

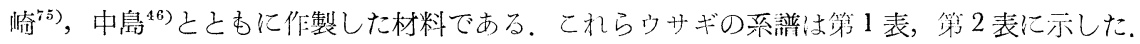

緒言に述べたようにこれら子孫ウサギではこの用状腙組織所見，血清 PBI 值， $I^{191}$ 掑取率，血中コレステ

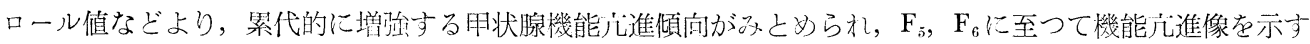

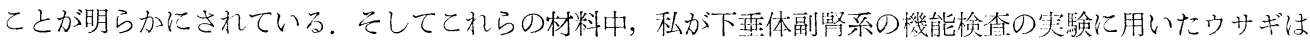

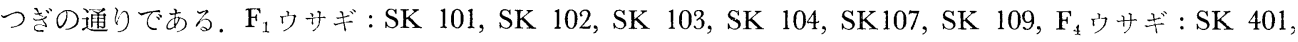
SK 402, SK 411, SK 412, SK 413, SK 414, SK 418, Fっウサギ：SK 501, SK 504, SK 505, SK 510, SK 514, SK 516, SK517, F SK 617 で，すなわち以上 $\mathrm{F}_{1} 6$ 例（オス 3 例，×ス 3 例)， $\mathrm{F}_{1} 7$ 例（オス 3 例，×ス 4 例)， $\mathrm{F}_{5} 7$ 例（オス 3

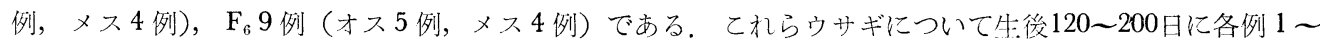
3 回検查を行なつた。つ热に $\mathrm{F}_{5}$ オス 3 例, メ久 3 例計 6 例 (SK 501, SK 504, SK 505, SK 514, SK 516, SK 517), $\mathrm{F}_{6}$ オス 3 例, メ久 3 例計 6 例 (SK 601, SK 602, SK 610, SK 613, SK 616, SK617) について 生後50日より180〜200日前後まで日を追つて検查を行なつた，

\section{(3) 歴代甲摘子孫 $F_{1} ， F_{4}$ ウサギ}

正常成熟オス，メスウサギに用摘を行ない，1 カ月以上してから交配し $F_{1}$ 在得， $F_{1}$ が成熟した恃に， $F_{1}$

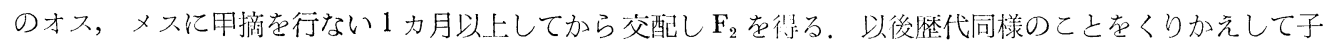

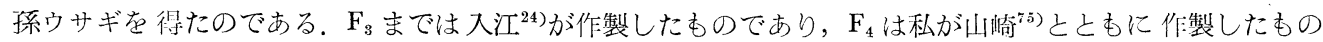
である。私が研究材料とした $F_{1}$ 沈入江とは别に私が川崎とともに作製したものである。これららサギの系

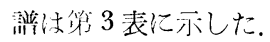

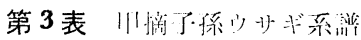
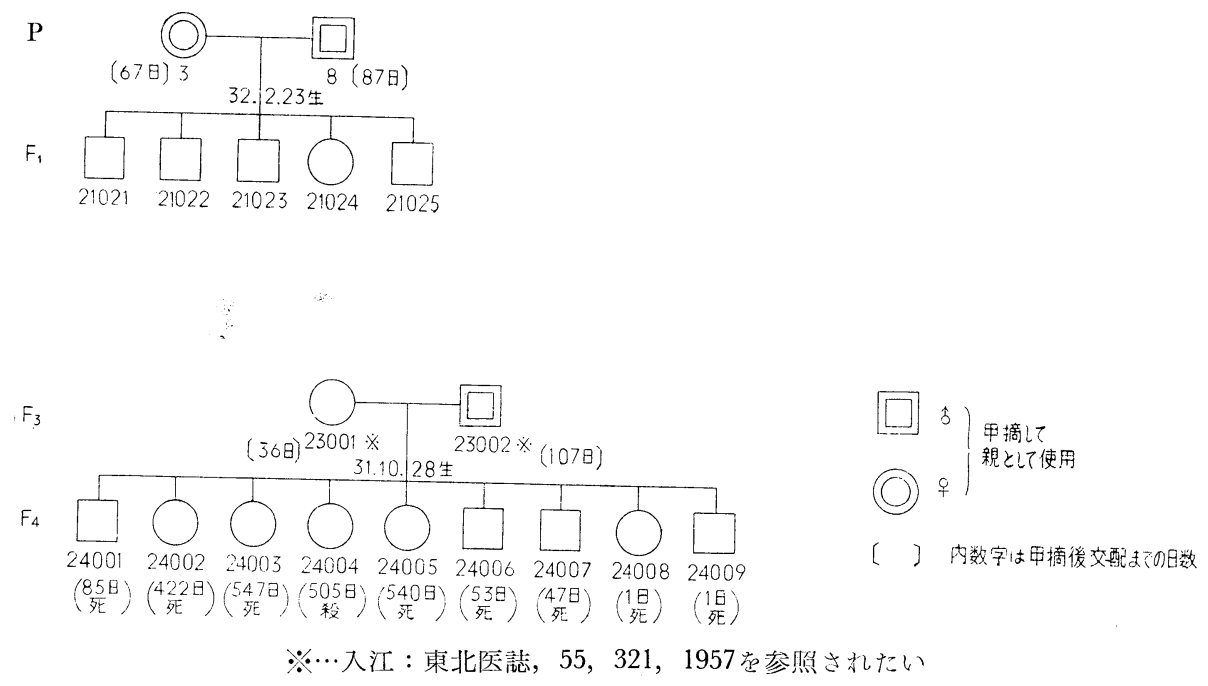

緒言で述べたように，乙れら子孫ウサギではその甲状腺組織所見，血清 PBI 值， ${ }^{121}$ 掑取率，血中コレス テロールなどより累代的に増強する忖状腺機能低下傾向が明らかにされている。私が下垂体副腎系の機能検 覔に用いた子孫りサギはつぎの通りである。すなわち，F $F_{1}$ ウサギは21021，21022，21023，21024，21025， $\mathrm{F}_{4}$ ウサギは24002，24003，24004，24005で，以上 $\mathrm{F}_{1} 5$ 例（オス 4 例，メス 1 例)， $\mathrm{F}_{4} 4$ 例（メ>のみ 4 例） である，これについて生後120〜200日にそれぞれ1〜3 回の榆查を行なつた。 


\section{(4) 甲末投与ウサギ}

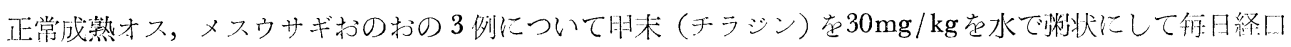

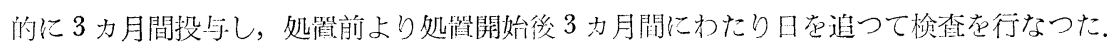

\section{(5) 甲摘ウサギ}

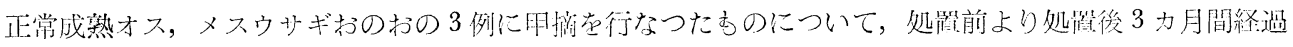
を追つて検查を行なつた。

\section{第 2 節 研究方法}

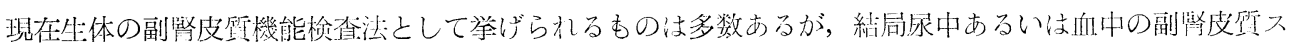

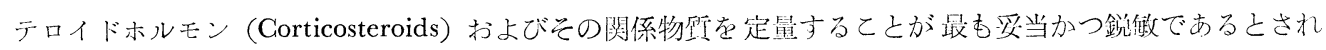

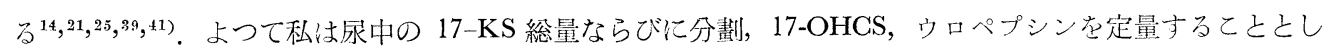

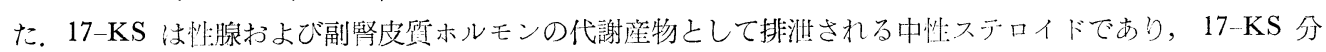

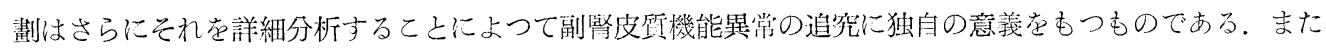
尿中に排泄される Glucocorticoids として 17-OHCS を定量した。ウロペプシン注最近永中 Corticosteroids

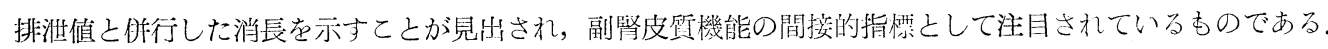

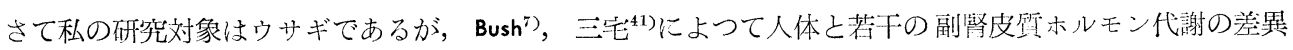
があるととが報告されている。すなわち，ウサギで注副肾皮啠分泌ホルモンは Hydrocortisone (Compound

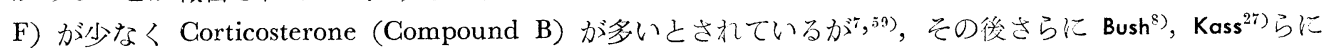
よつてウサギに ACTH を注射するととにより Comp. F の分泌量が Comp. B よりも多くなるとの郝告が あり，尿中 17-OHCS の定量はウサギにあ副腎皮澌機能検查汒として充分危用し得ると考光られる。

またりサギの尿中 17-KS については以前より若干の研究があり，とくに三它教授 ${ }^{99,411}$ はりサギを含む各

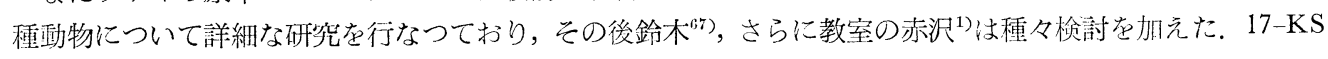

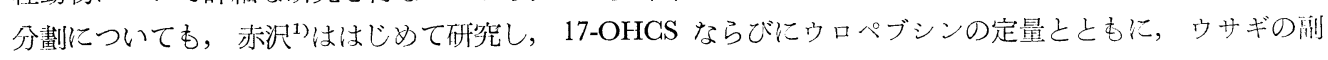
留皮質機能の检索にこれを応用している。私も鈴木，赤沢の報告にしたがつて測定した。

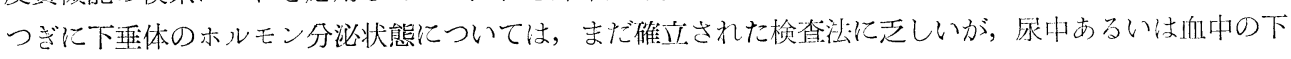
垂体性ホルモンを定量し判断するととが妥当と考光られる。最近 TSH, ACTH などの定量江汸硎究されて

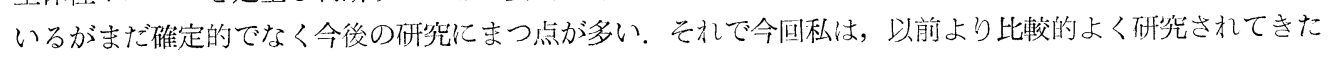
尿中のゴナドトロピンを定量するにとどめた。 あち万ん多くのホルモンを分泌する下䧿体の機能全般をゴナ ドトロピンの定量げけで云々するととはできないわけである。尿中ゴナドトロピンの定盗には以前より行わ れた生物学的検定法と, 最近 Crooke \& Butt ${ }^{9}$ によつて発表された化学的定量法の二つがある. 私汶化学们

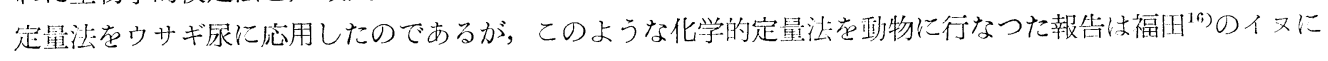
同守るの以外には見当らない上うである。

以上，下垂体前葉におけるゴナドトロピンの分泌状態および副婜皮質機能を知るために私が行なつた众圣 の種類とをれをえらんだ理的について述べたが，以下においてをのおのおのの测定す泛について速べるとと と方る.

\section{（1） ウサギ尿の 17-KS 総量測定法}

\section{A 测定原理}

生体の尿中亿排泄されるステロイドは50余の多数であるが，ステロイド核の17の位悄化ケトン基芷有する 中州:ステロイドを通常 17-KS と称し罢丸性の Testosterone, 副肾皮饮日来の Glucocorticoids 代㴬滻物,

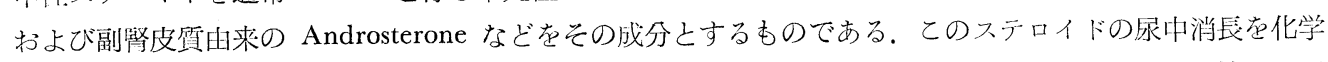
的に定量する原理は，尿中の水溶性: 17-KS 絬合物を酸によつて加水分解し，エーテルで抽出後䒬性ソーダ ならびに水でフェノール性 17-KS を除去し，ついでアルカリ性の下に m-Dinitrobenzene を作用させる。 活性ケトメチレン基は m-Dinitrobenzene と赤色の Zimmermann 反応物質を形成する。乙机を標集ステロイ

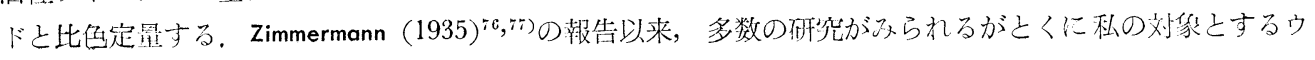


サギ尿の 17-KS 測定に際しては，Zimmermann 反忘呈色干涉物斦の除去にとくに留意する必要があり，その

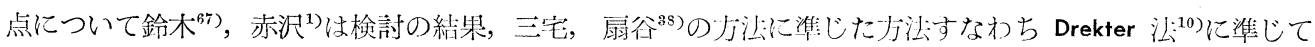
粗製尿エキスを作り，Pincus の Micro-Girards 法 ${ }^{55}$ に準じて非ヶトン分劃を除き，そのケトン分劃について Pearson 法 $^{54}$ に従い Zimmermann 反応を行ない $530 \mathrm{~m} \mu$ で比色定量した，私むとの方法によつた。

B 使用試蒋

(1) 濃塩酸

(2) エチルエーテル

(3) エチルアルコール

(4) $1 \%$ m-Dinitrobenzene-エタノ一ル溶液

(5) $10 \%$ 苛性ソーダ溶液

(6) 水酶瞈

第 1 図 尿中 17-KS 测定法

48 牌間尿 $\rightarrow$ 尿 $40 \mathrm{cc}+$ 濃塩酸 $12 \mathrm{cc}$ - 加水分解

$100 \mathrm{cc}$ 容量フラスコ

$80^{\circ} \mathrm{C} 30$ 分

冷却

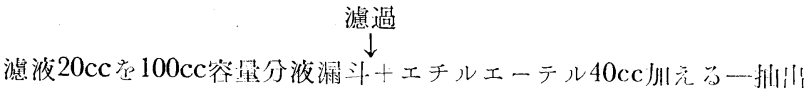

3 分間強振

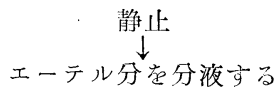

$\left.\begin{array}{r}10 \% \text { 菏性ソーダ水溶液 } 20 \mathrm{cc} \\ 20 \mathrm{cc}\end{array}\right\}$ 烝溜水 2 回洗桬一酸, フェノ一ル除士

エーテル分20cc学採取し, 蒸炎乾固する…(印性粗製エキス

非粗製エキス存純アルコール4 ccに溶解

皮酢酸 $0.5 \mathrm{cc}$, Girards $\mathrm{T}$ 試薬 $0.1 \mathrm{~g}$

$100^{\circ} \mathrm{C} 20$ 分加熱後冷却

水水 $10 \mathrm{cc}+10 \%$ 菏性ソー夕゙ $3 \mathrm{cc}$ 学加兊る

水層—エーテル20ccで 2 回詶

沈杽液でうすめた濃硫酸 $1 \mathrm{cc}$

分液漏斗

室温 2 時間放置

2 㭙間後濃硫酸 $1 \mathrm{cc}$ 党加え万

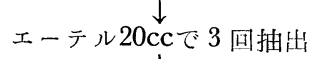

エーテル分を $2.5 \%$ 炭酸ソーダ $20 \mathrm{cc}$ で洗う

蒸溜水 $20 \mathrm{cc}$ で 3 回洗う

エーテル分蒸発乾固…(ケトン分劃)

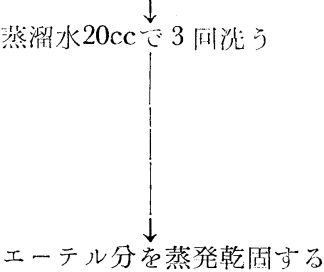

エーテル分蒸発乾固与る

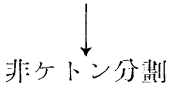

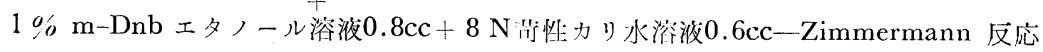

$25^{\circ} \mathrm{C} \pm 0.1^{\circ} \mathrm{C}$

20 分加温後冷却 $+$

稀釈液 $2 \mathrm{cc}$

比色測定 $(530 \mathrm{~m} \mu)$ 一测定 
(7) Girards 郭檪

(8) 濃硫酸

（9）８ N苛性力り水溶液

$\mathrm{C}$ 測定操作

第1図に示した通りである。㭢準曲線は Dehydroisoandrosterone を用いて伓製した。図示したう法によ

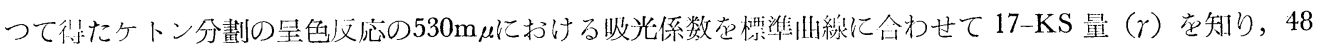
壯間尿量より48時間尿中の $17-\mathrm{KS}$ の排泄值を得た。

\section{(2) ウサギ尿の 17-KS 分劃測定法}

\section{A 測定原理}

尿中 17-KS の主要構成成分は Androsterone, Eticholanolone, Dehydroisoandrosterone などであるが， Hechter \& Pincus $^{20)}$ ，Masuda ${ }^{35}$ ，鈴木 ${ }^{66}$ 亿よれば各分劃の ステロイド代謝に占める位置はそれぞれ異なり， 各分劃は独自の意義をあつものである．故に 17-KS 総量と同時に 17-KS 分劃を測定するととによつて, 副腎皮質の機能およびそのステロイドホルモン代謝の様相をより詳細に知ることができる。 また 17-KS 総 量として測定している Zimmermann 反応呈色物質中には副腎皮質および性腺以外のステロイドその他の物質 あある程度干渉してくるようであり，とくにウサギについてはその点多少の注意を要する ${ }^{39,41)}$. よつて Chromatography によつて 17-KS をさらに詳しく分析することは重要な意味をあつあのである. 実施方法に

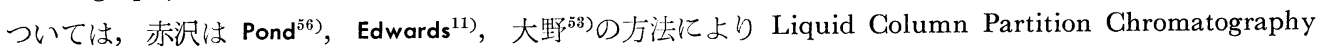
をウサギ尿の 17-KS 分劃測定に応用して好成䋶を得た. 私もこれと同じ方法によつた.

B 使用試薬

(1) 吸着剤 Brockman の活性アルミナ

(2) 溶剂

1）精製無水ベンゼン

2）精製然水エタノール

3）溶出ブログラム

$$
\begin{aligned}
& 0.05 \mathrm{Vol} \% \text { エタノール含有ベンゼン } 30 \mathrm{cc}(2 \mathrm{cc} \times 15 \text { 柿 }) \\
& 0.2 \mathrm{Vol} \% \text { エタノール含有ベンゼン } 30 \mathrm{cc}(2 \mathrm{cc} \times 15 \text { 本 }) \\
& 1.0 \mathrm{Vol} \% \text { エタノール含有ベンゼン } 20 \mathrm{cc}(2 \mathrm{cc} \times 10 \text { 本 }) \\
& \text { 純エタノール } 6 \mathrm{cc}(2 \mathrm{cc} \times 3 \text { 本 })
\end{aligned}
$$

（3）尿ケトン分劃の精製および Zimmermann 反応用試楽 17-KS 総量の項に述べた通りである.

G 測定操作

測定装置として大野の院王式 ${ }^{33}$ とよつた. 垁施方法は，17-KS 総量測定後の尿を用いて $600 \gamma$ 相当の㽷呈 よりケトン分劃を抽出し，ベンゼン $1 \mathrm{cc}$ に溶解させ，上記の吸着剤をつめた Column に注入し，まず0.05 $\mathrm{Vol} \%$ エタノール含有ベンゼンで $90 \mathrm{~mm} \mathrm{Hg}$ 除压で溶出する. $2 \mathrm{cc}$ あて15榕出しついで0.2Vol\%エタノール 含有ベンゼンで $2 \mathrm{cc} 15$ 本， $1 \mathrm{Vol} \%$ エタノール含有ベンゼンで $2 \mathrm{cc} 10$ 本，さらに純エタノール $2 \mathrm{cc} 3$ 本，合

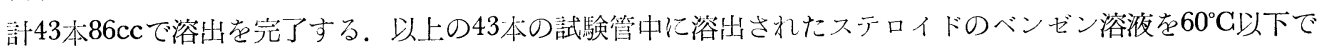
沜温減圧乾固する１7-KS 総量の項で述べた Zimmermann 反応を行ない，比色定量する．試験管番号を橫䡉 にとり，17-KS 量 $(\gamma)$ を縦軸にとれば，つぎの試験管番号に応じてそれぞれ 8 個の分劃に分れる.

\section{試験管番号 分劃相当する $17-\mathrm{KS}$}

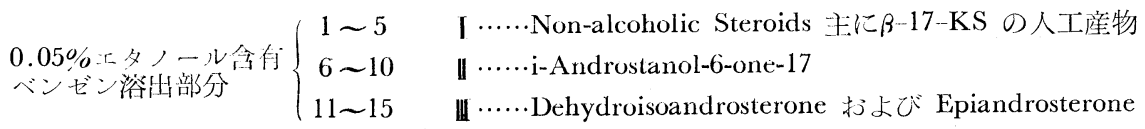

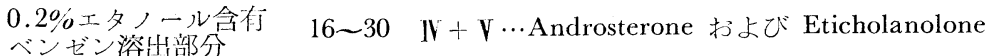




$$
\begin{aligned}
& \begin{array}{ll}
1 \% \text { 多 } \\
\text { ンゼン溶出部分 }
\end{array} \\
& \text { 純エタノール溶出部分 } 41 〜 33 \text { VII.....色素および不明のステロイド }
\end{aligned}
$$

このようにして各分劃の 17-KS 量 $(\gamma)$ の総和 $(\gamma)$ に対する百分率を計算し，48壯間排泄 17-KS 総量加 ら各分劃の絶刘傎在得た。

\section{(3) ウサギ尿の 17-OHCS 測定法}

A 测定原理

副䈔皮啠より分泌されるステロイドホルモン (Corticoids) は, Hydrocortisone, Cortisone などでありい ずれも生物学的活赃をあつホルモンとしてそのままの形で㽷中に排泄される。乙れらは Glucocorticoids と 称されるものであり，乙れらを化学的に測定すること（Chemocorticoid）は Cortisone, Hydrocortisone の

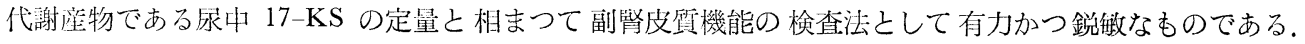
Hydrocortisone, Cortisone は 17,21-dihydroxy-20-keto の化学構造をむつステロイドであり, Porter \& Silber $(1950)^{5 \pi}$ によつて発表されたいわゆるPorter-Silber 反応を応用して定量される。すなおち 17,20-dihydroxy-20-keto の位置に Phenylhydrazine を反応させ $410 \mathrm{~m} \mu$ で最高の吸光度をもつ黄褐色の Bisphenylhydrazone 在形成し，乙れ在比色定量する。尿中 17-OHCS 定量法には Porter \& Silber の発表以来多くの報 告があるが，Reddy らゔのう法によると尿よりnーブタノールで絬合型，遊晟型を併せて抽出するのであり， この方法が最も一般的に行なわれてきた。 その後 Smith ら ${ }^{63}$ はさらに Reddy らの方法に改良を加えた方法 を発表したが，現在 Corticoid の抽出にn-ブタノールを用いる方法の中では最むすぐれたすのとされている. 私はSmith 法をウサギに灾用し，三宅教授ら ${ }^{40}$ のその後の吟味を参考として測定を行なつた。 ウサギ㽷中に は，Porter-Silber Chromogen が比較的少ないので，私はとくに測定操作中での Corticoids の損失を少な くするととに留意した。

B 使用試薬

(1) $0.01 \mathrm{~N}$ 硫酸

(2) $18 \mathrm{~N}$ 硫酸

(3) $0.1 \mathrm{~N}$ 苛性ンーダ

(4) 水酶酸

(5) 化学用精製恉荻末

(6) 期洋滤䋊 No. 2

(7) Phenylhydrazine- 硫酸溶液

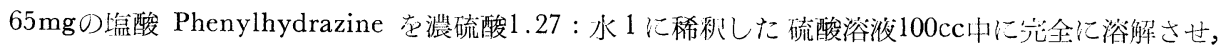
测定值前に䀘整して使用与る。

(8) 硫酸溶液 湍硫酸 $1.27:$ 水 1 (流酸 $280 \mathrm{cc}:$ 水 $220 \mathrm{cc}$ ) で洞製する。

(9) n-ブタノール

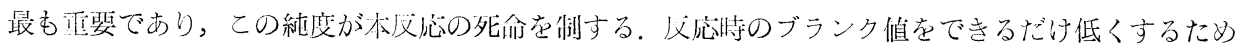
に，精製する必琵がある。私は鳥井汒“22) 応用して再蒸溜を行ない精製した。

C 測定操作

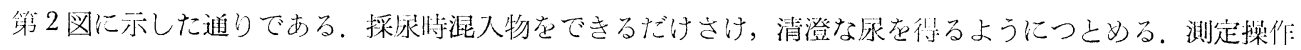

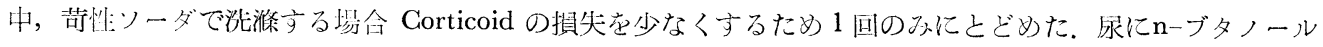

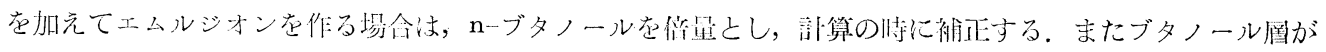

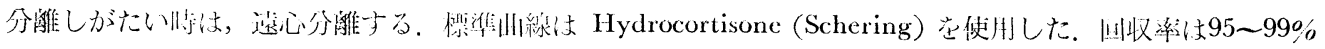

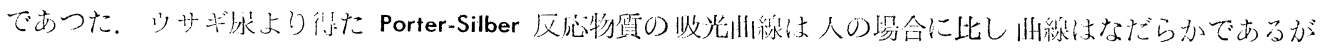

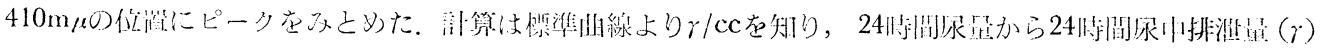


第 2 図 尿中 17-OHCS 測定法

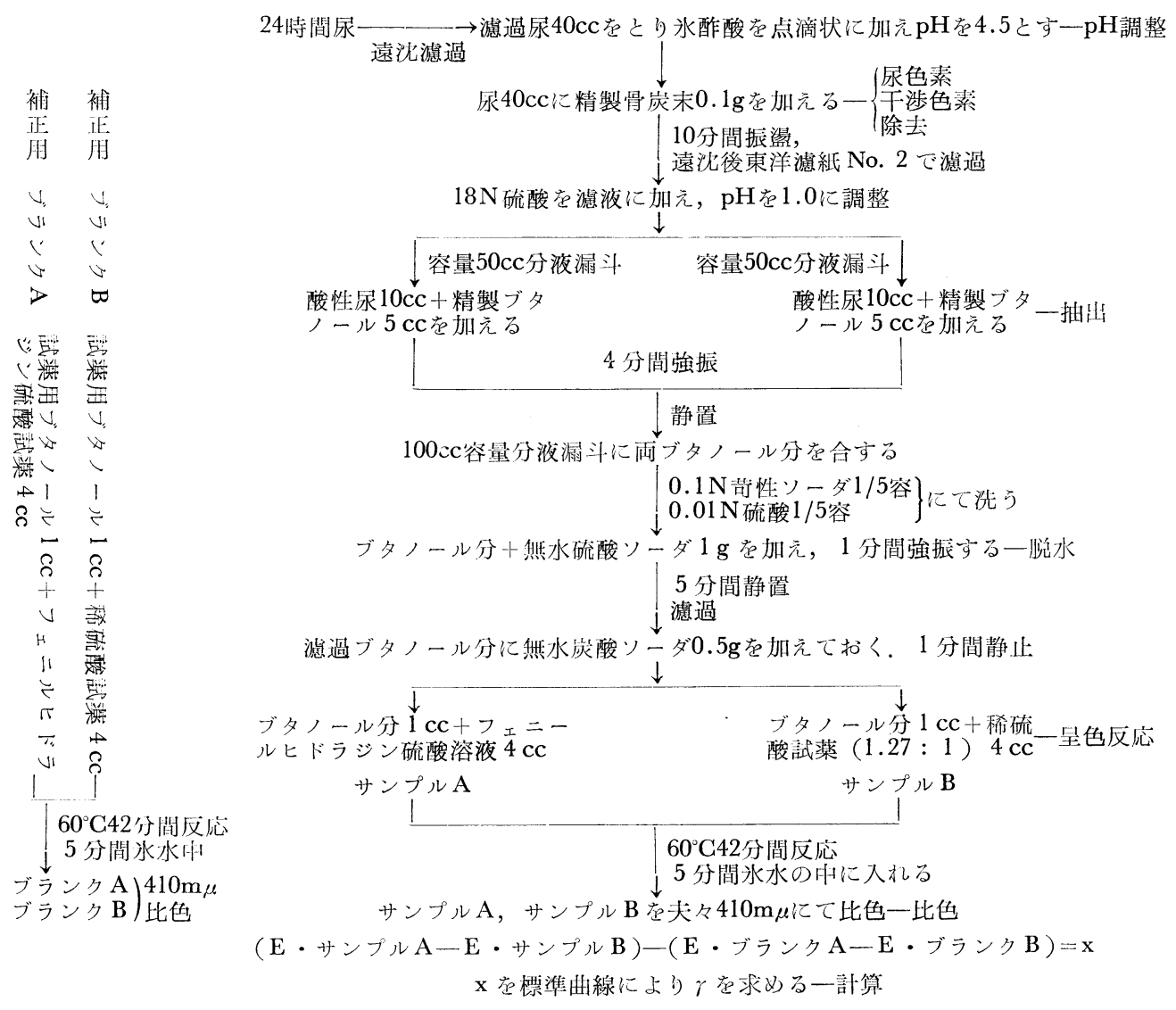

企往た。

\section{(4) ウサギ尿のウロペプシン測定法}

A 測定原理

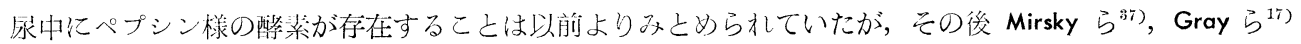
によつてウロペプシンは胃壁より血中に分泌されたものが永中に排洲されることが明らかになつた，さらに Gray ${ }^{18)}$ はウ口ペプシンについて詳細な研究を行ない，ウロペプシンの排泄状態は半自働的に副珡皮質機能に 併行して消長することを見出し，さらに Krakaver ら ${ }^{30}$ はり口ペプシンと尿中 17-KS，17-OHCS 值はよく昨 行して増減するてとを発表して以来，注目をひくに至つた。すなわちウロペブシンの消長は副腎皮質機能の 間接的指標として重要な意義をむつようになつた。 ウロペプシンの測定には現在二方汒がある.

(1) 蛋白分解能測定法 (ヘモグロビン法)

Anson \& Mirsky ら²によつて発表されたものである. その原理はベブシン虐へモグロビンに作用させてチ ロジンを遊離させ，生じたチロジとフェノール試楽を反応させ青色の反応物留を彷て比色定量するのであ 万.

(2) 凝乳能測定江;

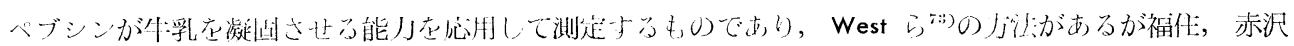

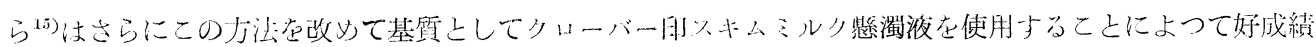

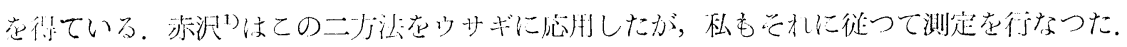


B 使用試薬

1 蛋白分解能測定汒:

(1) $3.5 \mathrm{~N}$ 塩酸および $0.33 \mathrm{~N}$ 䧼酸

(2) $2.5 \%$ 酸化へモグロビン溶液

(3) $0.5 \mathrm{~N}$ 苛性ソーダ

(4) $0.3 \mathrm{M}$ 三塩化酢酸

(5) Folin-Ciocalteu 彺悲

2 凝乳能測定江:

(1) クローバー印スキムミルク（粉乳）

(2) $\mathrm{pH} 4$.9酢酸䌊衝液

第3図ウ口ペプシン測定法（へモグロビン法）

24 時間尿 (12時間透析) $3.5 \mathrm{~N}$ 塩酸に上

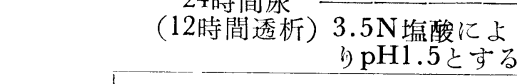

陖性尿 $1 \mathrm{cc}+3$

塩化酢酸 $10 \mathrm{cc}$

$2.5 \%$ 酸化へモグロビ

ン溶液 $5 \mathrm{cc}$ 老加元る

東洋濾紙 No. 2 で滤過

濾液 $2 \mathrm{cc}+1.2 \mathrm{cc}$ 稀秎 Folin-Gio calteu 试薬 $+0.5 \mathrm{~N}$ 䔩性ソーダ $4 \mathrm{cc}$

$$
\begin{aligned}
& \text { 15分間放笝 } \\
& 560 \mathrm{~m} \mu \text { にて比色 } \\
& \text { B (吸光度) }
\end{aligned}
$$

酸性尿 $20 \mathrm{cc}$ 营蒸溜水により $25 \mathrm{cc}$ 迄うすうる一稀㗭<smiles>C[Te]</smiles>

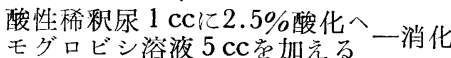
$37^{\circ} \mathrm{C} 1$ 時間温浴 $0.3 \mathrm{M} 3$ 塩化酢酸 10 未消化へモグロ cc在加えょく混和一ビン色素除去 東洋濾紙No. 2 で滤過 濾液 $2 \mathrm{cc}$ 亿 $1.2 \mathrm{cc} の$ Folin-Cio calteu 弑薬
（但蒸溜水 3 , 本液 $1 \mathrm{cc} の$ 割にうすめたた (但蒸溜水 3 , 本液 $1 \mathrm{cc} の$ 劃にうす女たも一是色反灾 の）及び $0.5 \mathrm{~N}$ 苛性ソーダ $4 \mathrm{cc}$ を加える

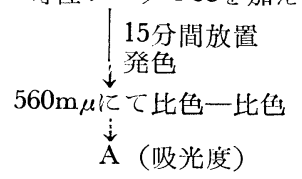

$\mathrm{A}-\mathrm{B}=$ 消化により遊䨀されたチロジン様物筫 相当吸光度

第 4 図ウロペプシン測定法（凝乳能法）

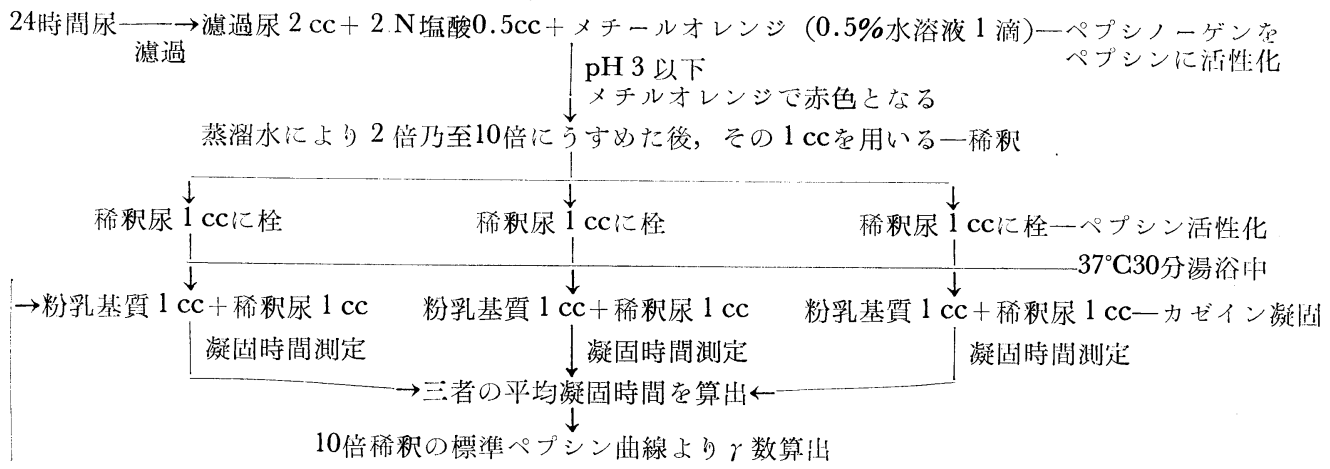

一粉乳基質作製（測定再:新調）

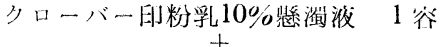

$$
\begin{aligned}
& \mathrm{pH} 4.9 \text { 酰酸緩衝液 } 4 \text { 谷 }
\end{aligned}
$$

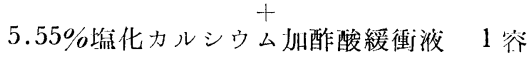


(3) $5.55 \%$ 塩化力ルシウム加酢酸緩衝淮

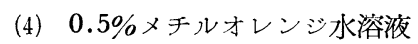

(5) 2 N塩酸

G 測定操作

第 3 図，第 4 図に示した通りである。ウサギ承について測定する䶍命，へモグロビン法ではブランク值の 高い場合は㽷の透析を必要とすることがあると赤沢は述べている。

\section{（5） ウサギ尿のゴナドトロピン測定法}

\section{A 測定原理}

ゴナドトロピンに関する研究はかなり以前より進められており，他の脸下垂体ホルモンがまだ不明の点が 多いのにくらべて, その生物学的特性, 抽出法, 物理化学的性状などは現在非常に明らかにされている ${ }^{47}{ }^{69}$. 動物のゴナドトロピンについても研究されており，Thimann ${ }^{69}$ によるとゴナドトロピンの化学的組成は人とほ とんど同様であり，数種のアミノ酸とマンノースおよびグルコサミンより成る糖蛋白であるといわれる.

さて㽷中に排泄されるコナドトロピンの定量法については現在までとの生物学的特性を応用した生物学的 定量法が多く行なわれてきた，尿より抽出したゴナドトロピンを幼若雌性マウスに注射し，マウス子宮重髽 の増加度をむつて定量するあのであるが，検定に使用する材料が動物であることから，生物学的検定法一般 に通ずる難点として完全に一定の条件が得難いことが挙げられる ${ }^{36,52)}$. ゴナドトロピンの化学的組成が明ら かになつた現在, 化学的定量法が期待されていたが, 1954年 Crooke \& Butt ${ }^{9}$ によつて Column Chromatography を忍用した方法が発表された，このう泛の特徵は，コナドトロピンを濾胞刺㦸ホルモン（FSH）上 黄体形成ホルモン (LH) に分離定量できることである。これいは生物学的定量法では不可能である。ゴナド トロピンは明睹な生物学的活性をむつホルモンであり，化学的に定量した值が生物学的活性を走すホルモン

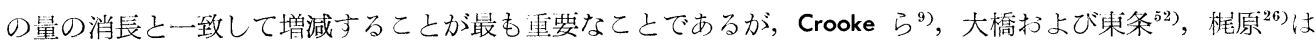
闫者㥙よく一致して増減することをみとめている。

化学的定量法は抽出されたゴナドトロピンを Column Chromatography によつて FSH，LH に分け，

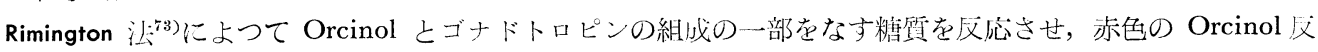
忍物質を比色定量するものである。ウサギ尿にこのノ法を用いた報告は見当らないが，私は化学的定量法在 ウサギに応用し，またその生物学的活性についても若干の梌定を行なつた。

B 使用試楽

(1) $20 \%$ オリン狀㵧淮

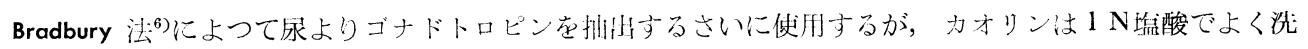
い溜水で洗涤後乾燥して使用する。

(2) $1 \mathrm{~N}$ アンモニア溶液

(3) 水酢酸

(4) $95 \%$ 办多一ー

(5) アセトン

(6) 生理的食塩水

(7) 燐酸三カルシウム

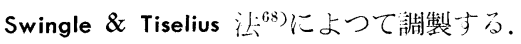

Chromatography の收着剂として使用なる。

(8) Hyflo-Super-Cel (Johns Manville 製)

(7) と混合して吸着郕とする。

(9） $0.002 \mathrm{M}$ 第二燐酸り一夕浴液

(10) $0.02 \mathrm{M}$ 棌三燐酸り一父溶淮

(11) $80 \mathrm{Vol} \%$ 琉酸溶淮 
(12) Orcinol 觟楽

$30 \mathrm{Vol} \%$ 硫酸溶液に $1.6 \% 0$ 制会にOrcinol試桨を完全に浴解して使用する。文心を行なう度每に調製する。

G 測定操作:

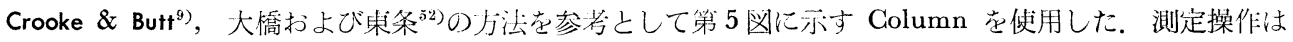
第 5 図，第 6 図に示す通りである。標準物瞔としては現在まだ純粋な FSH，LH が得られないため，萄栽糖 を標準として標準曲線を作製した。これから，㽷より抽出したゴナドトロピンの Orcinol 反応物質の $\gamma$ 量を 知り，24時間尿量から 24 時間排泄值を $r$ as Glucose として示した。すなおちこれてはゴナドトロピンの絶刘

第 5 図尿中ゴナドトロピン定量法（化学的定量法）

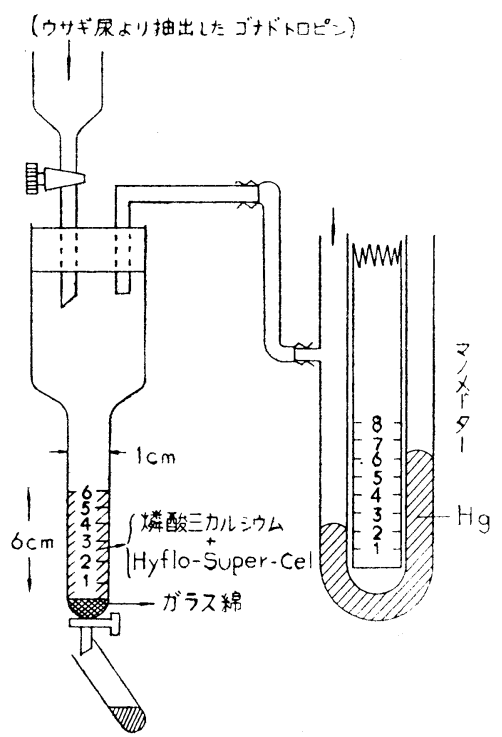

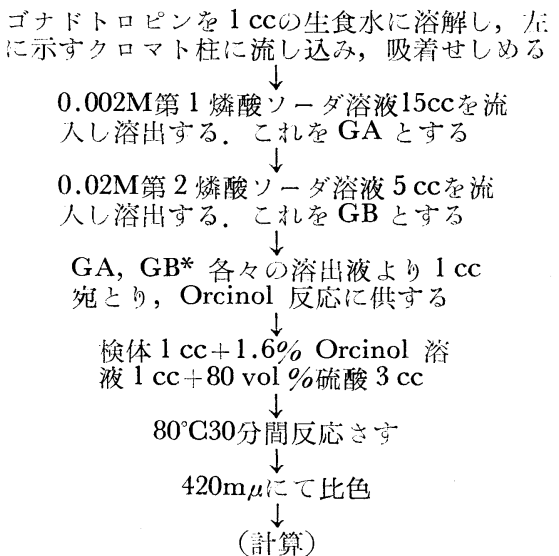

II 位: $\gamma$ as Glucose/24時音

(iit)

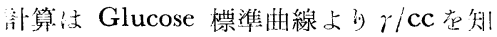
门，溶出液量上可原尿 $100 \mathrm{cc}$ 分心量进計 算し，之れよ可更に24時開尿中排泄量が 得ら机。。

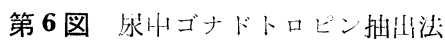

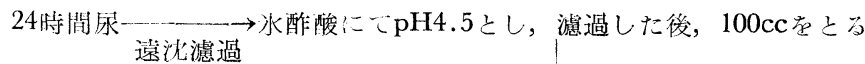

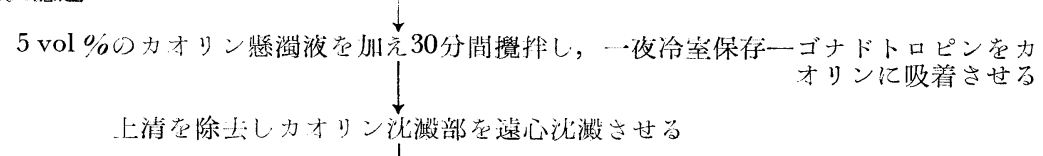

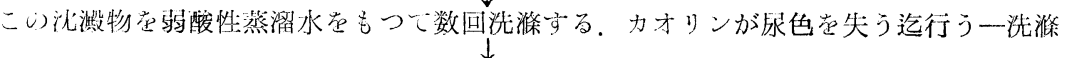

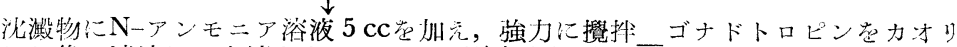

した後，遠沈し，上清をとる。乙れを再度く句返すーシょりアンモニアへ抽出

上記抽出液を氷酢酸にてpH8.5とし，不純物を遠心沈測にて除き，更にpH5.5とする

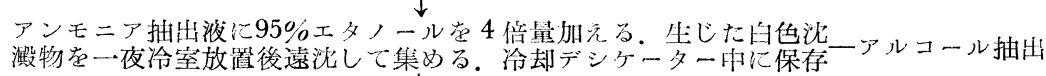

点沈除去し，上清に冷了七

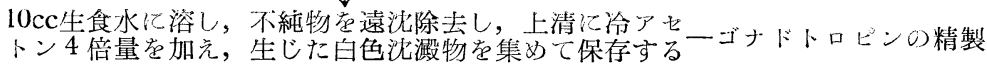
以上の操作によつて得たゴナドトロピン（白色粉未）点定量に供する 
量を示すのではなく，相刘的な意味をもつあのである.

ウサギ尿より抽出されたゴナドトロピンの Orcinol 反応物質の收光曲線は第 7 汹の通りであり，FSH， LH いずれも $420 \mathrm{~m} \mu て ゙$ 最高财光度を示している，このことより，ウサギ尿より抽出されたゴナドトロピンは Orcinol と糖反応を起こしていることが察知できる。 また抽出されたゴナドトロピンの生物学的作用をマウ ス子宮重量法 ${ }^{52}$ によつて証明することができた，FSH，LH についてあ三宅先の方法により，それでれの作 用があることを確認することができた。

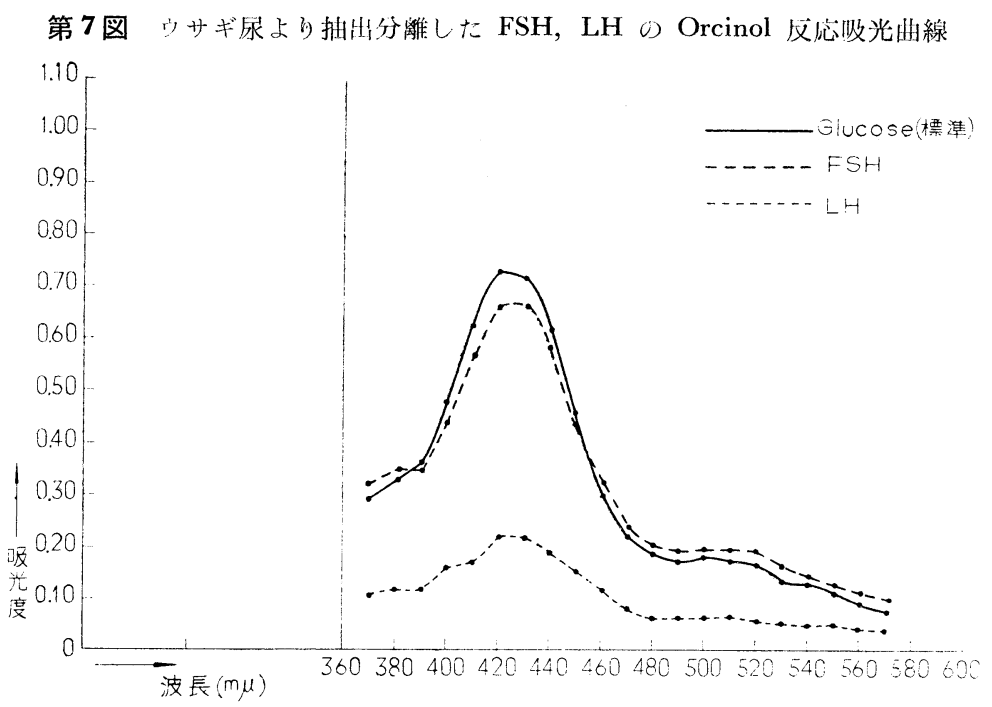

\section{第 3 章 測 定 成 績}

\section{第 1 節 対照正常ウサギ（第 4 表，第 5 表）}

\section{（1）尿中 17-KS 総量測定成績}

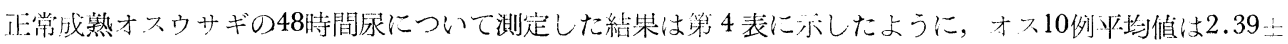
$0.08 \mathrm{mg} / 48$ 時間，メス10例平均值は $2.25 \pm 0.08 \mathrm{mg} / 48$ 時間である。.また，才ス，メスおうおの 5 例について

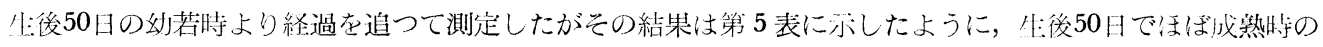
值の1/3を示し, 生後70-80日で1/2となり，生後120日以後は成熟時の值を示している。生後70日までオ久，

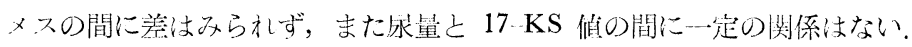

\section{(2) 尿中 17-KS 分劃測定成績}

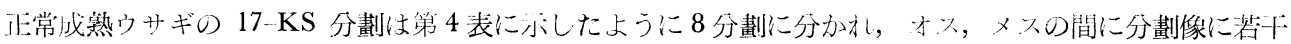

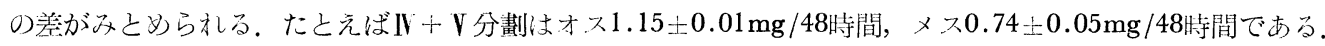

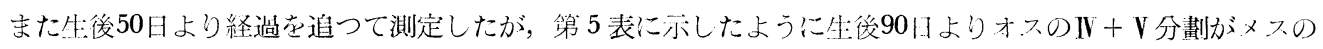
それよりも高值走している。また生後120日以㣪に㧍いて成熟势の分劃像に一致することがる上りられる。

\section{（3）尿中 17-OHCS 測定成績}

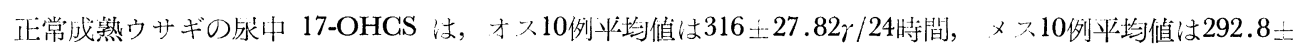

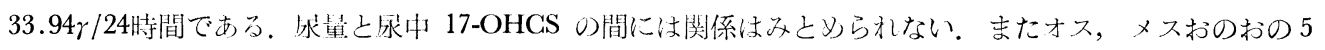
例について生後50日より経過在追つて測定した絬果は，第 5 表に示したように生後50日で成熟時の $1 / 3$ の䇚

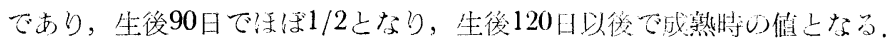

\section{(4) 尿中ウロペプシン測定成績}


第 4 表 正常成熟ウサギの尿中 17-KS 総量, 17-KS 分劃, 17-OHCS，ウロペプシン， ゴナドトロピン排泄值（雌雄各10例平均值）

\begin{tabular}{|c|c|c|c|c|c|c|c|c|c|c|c|c|}
\hline & \multirow{2}{*}{$\begin{array}{c}17-\mathrm{KS} \\
\text { 総量 } \\
(\mathrm{mg} / 48 \mathrm{~h})\end{array}$} & \multicolumn{7}{|c|}{ 17-KS 分劃 $(\mathrm{mg} / 48 \mathrm{~h})$} & \multirow{2}{*}{$\begin{array}{l}17- \\
\text { OHCS } \\
(\gamma / 24 h)\end{array}$} & $\begin{array}{c}\text { ロペプシン } \\
(/ 24 \mathrm{~h})\end{array}$ & \multicolumn{2}{|c|}{$\begin{array}{l}\text { ゴナドトロピ } \\
\text { ン }(\gamma / 24 h)\end{array}$} \\
\hline & & $\mathrm{I}$ & $\|$ & III & $\mathrm{N}+\mathrm{V}$ & VI & VII & VIII & & 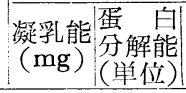 & FSH & $\mathrm{LH}$ \\
\hline 成熟令 & \multirow{2}{*}{\multicolumn{12}{|c|}{ 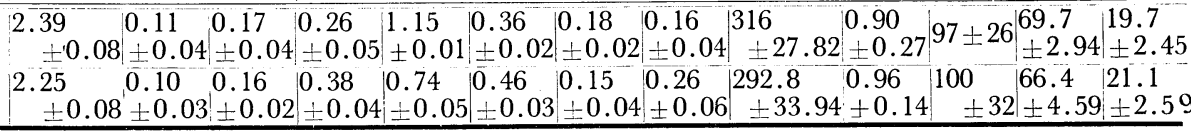 }} \\
\hline 成熟早 & & & & & & & & & & & & \\
\hline
\end{tabular}

第 5 表 正常幼若ウサギの尿中 $17-\mathrm{KS}$ 総量，17-KS 分劃，17-OHCS，ウロペプシン， ゴナドトロピン排泄值（雌雄各 5 例平均值）

\begin{tabular}{|c|c|c|c|c|c|c|c|c|c|c|c|c|c|}
\hline \multirow{2}{*}{ 生後 50 日 } & 今 0.814 & 0.10 & 0.13 & 0.014 & 0.25 & 0.24 & 0.03 & 0.05 & 110 & 0.15 & 17 & 20 & 8.3 \\
\hline & 우 0.819 & 0.094 & 0.136 & 0.01 & 0.255 & 0.24 & 0.04 & 0.044 & 100 & 0.16 & 16 & 20 & 8.0 \\
\hline \multirow{2}{*}{60 日 } & 今̂ 0.89 & & & & & & & & 115 & 0.21 & 22 & 21 & 8.0 \\
\hline & 우 0.91 & & & & & & & & 110 & 0.18 & 20 & 21 & 8.3 \\
\hline \multirow{2}{*}{70 日 } & $\mid \hat{o} 1.07$ & 0.11 & 0.14 & 0.16 & 0.33 & 0.25 & 0.04 & 0.04 & 120 & 0.28 & 30 & 29.3 & 10.2 \\
\hline & 웃 1.09 & 0.11 & 0.14 & 0.16 & 0.33 & 0.25 & 0.05 & 0.05 & 120 & 0.27 & 30 & 28.0 & 10.0 \\
\hline \multirow{2}{*}{80 日 } & 令 1.32 & & & & & & & & 130 & 0.37 & 38 & 29 & 10.5 \\
\hline & 우 1.18 & & & & & & & & 136 & 0.35 & 40 & 30.5 & 11.0 \\
\hline \multirow{2}{*}{90 日 } & $\hat{\circ} 1.44$ & 0.106 & 0.14 & 0.23 & 0.556 & 0.25 & 0.07 & 0.09 & 155 & 0.45 & 46 & 32 & 11.8 \\
\hline & of 1.24 & 0.08 & 0.14 & 0.23 & 0.376 & 0.26 & 0.10 & 0.06 & 160 & 0.46 & 50 & 31.5 & 11.0 \\
\hline \multirow{2}{*}{ 100日 } & 今̂ 1.86 & 0.11 & 0.17 & 0.25 & 0.77 & 0.32 & 0.12 & 0.12 & 210 & 0.48 & 50 & 51 & 19.5 \\
\hline & 우 1.61 & 0.10 & 0.15 & 0.28 & 0.48 & 0.33 & 0.14 & 0.13 & 184 & 0.47 & 49 & 52 & 20.0 \\
\hline \multirow{2}{*}{110 日 } & 今ิ 2.16 & & & & & & & & 280 & 0.70 & 62 & 60.3 & 20.2 \\
\hline & 우 1.99 & & & & & & & & 260 & 0.56 & 65 & 60 & 22.3 \\
\hline \multirow{2}{*}{120 日 } & 今ิ 2.40 & 0.13 & 0.17 & 0.25 & 1.15 & 0.36 & 0.17 & 0.16 & 321 & 0.87 & 95 & 69.6 & 19.2 \\
\hline & 온 2.23 & 0.10 & 0.16 & 0.374 & 0.73 & 0.45 & 0.164 & 0.25 & 294 & 0.83 & 94 & 63.2 & 22.0 \\
\hline \multirow{2}{*}{ 130日 } & 㑒 2.39 & & & & & & & & 315 & 0.90 & 97 & 68.0 & 20.0 \\
\hline & 우 2.20 & & & & & & & & 300 & 0.96 & 104 & 66.3 & 24.0 \\
\hline \multirow{2}{*}{ 150日 } & |今 2.39 & 0.12 & 0.17 & 0.26 & 1.15 & 0.35 & 0.18 & 0.16 & 310 & 0.91 & 99 & 72.0 & 21.0 \\
\hline & 오 2.20 & 0.09 & 0.16 & 0.36 & 0.71 & 0.44 & 0.16 & 0.28 & 316 & 0.93 & 100 & 65.2 & 22.5 \\
\hline \multirow[t]{2}{*}{ 180日 } & 令 2.43 & & & & & & & & 322 & 0.88 & 98 & 70.5 & 19.0 \\
\hline & 우 2.23 & & & & & & & & 310 & 0.90 & 94 & 63.0 & 19.0 \\
\hline \multirow[t]{2}{*}{210 日 } & 今ิ 2.41 & 0.12 & 0.18 & 0.25 & 1.15 & 0.36 & 0.17 & 0.18 & 317 & 0.87 & 83 & 68.0 & 18.0 \\
\hline & 오 2.23 & 0.10 & 0.17 & 0.37 & 0.73 & 0.43 & 0.17 & 0.26 & 285 & 0.89 & 80 & 68.0 & 21.0 \\
\hline \multirow{2}{*}{300 日 } & 令 2.42 & 0.13 & 0.166 & 0.25 & $|1.156|$ & 0.35 & 0.20 & 0.17 & 305 & 0.70 & 86 & 69.0 & 18.5 \\
\hline & 우 2.21 & 0.11 & 0.17 & 0.35 & 0.70 & 0.46 & 0.17 & 0.25 & 297 & 0.80 & 92 & 67.2 & 17.0 \\
\hline
\end{tabular}

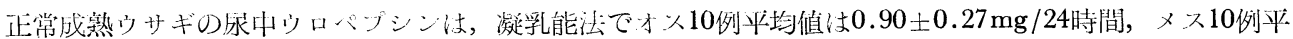
均值は $0.96 \pm 0.14 \mathrm{mg} / 24$ 時間，蛋白分解能法ではォス 10 例平均值は $97 \pm 26$ 単位 $/ 24$ 時間，メ又 10 例平均值は $100 \pm 32$ 单位 $/ 24$ 時閒である。才フ，メフおのおの 5 例について生後 50 日より測定した結果，第 5 表に示した 


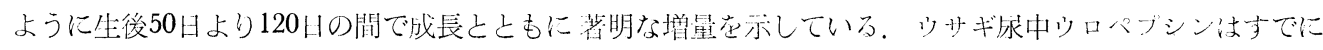
述べた 17-KS, 17-OHCS とよく一致した消長在示しており，Corticoids 分泌状態の間接的指標となり得る ことが以上の成績からも理解される。

\section{（5）尿中ゴナドトロピン測定成績}

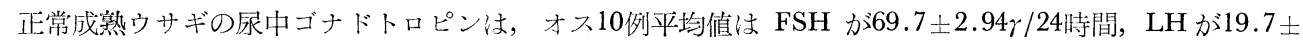

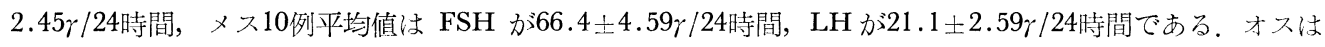
メスより FSH は若干高い值を示すようである，尿量とゴナドトロピンの間には関係はみよもられない，つ

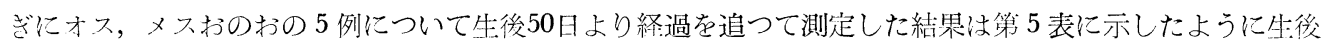

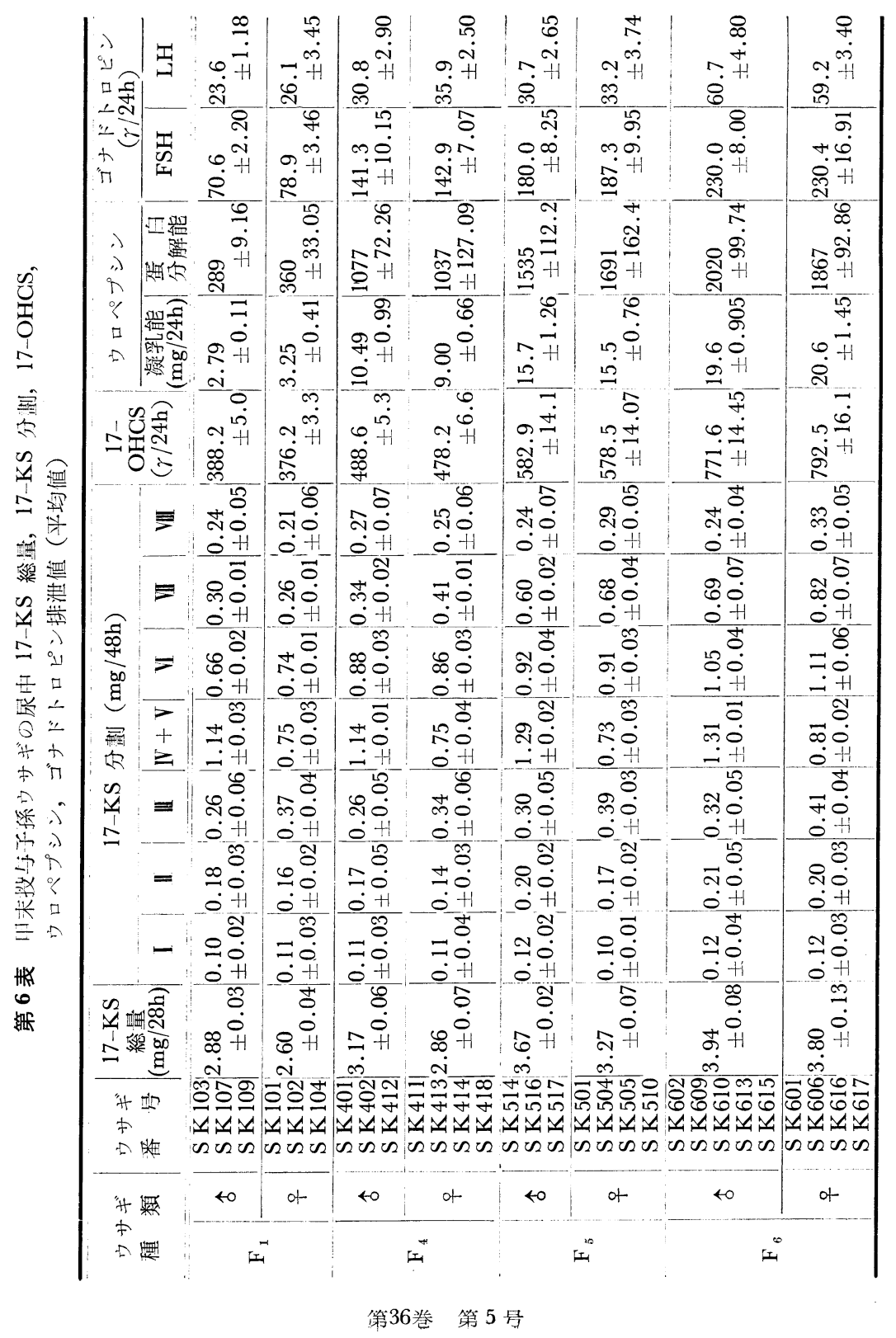




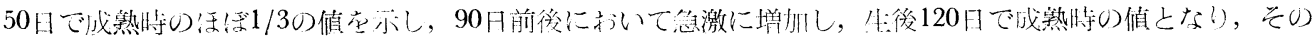
後も同様の值を示していら。

\section{第 2 節 歴代甲末投与子孫ウサギ（ $\left.F_{1}, F_{4}, F_{5}, F_{6}\right)$ \\ 1 成熟時の測定成績 $\left(F_{1}, F_{4}, F_{5}, F_{6}\right)$ (第 6 表)}

\section{(1) 尿中 17-KS 総量測定成績}

$\mathrm{F}_{1}$ ではオ> 3 例平均值は $2.88 \pm 0.03 \mathrm{mg} / 48$ 侍間，メ以 3 例半侍值は $2.60 \pm 0.04 \mathrm{mg} / 48$ 将間， $\mathrm{F}_{4}$ ではオス 3

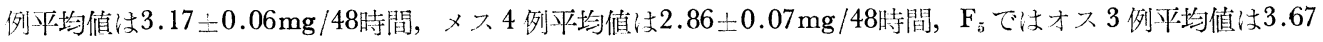
$\pm 0.02 \mathrm{mg} / 48$ 時間，メス 4 例平均值は $3.27 \pm 0.07 \mathrm{mg} / 48$ 時間， $F_{6}$ ではオス 5 例平均值は $3.94 \pm 0.08 \mathrm{mg} / 48$ 㭙

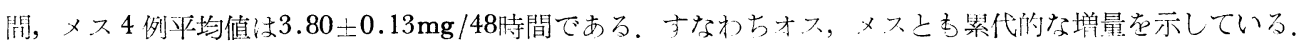

\section{（2）尿中 17-KS 分劃測定成績}

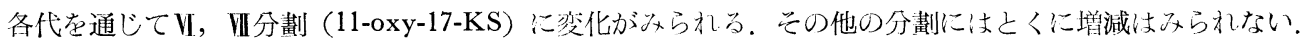

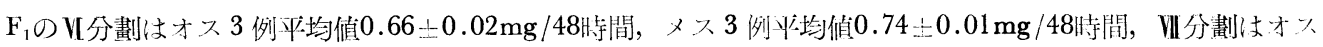
3 例平均值 $0.30 \pm 0.01 \mathrm{mg} / 48$ 時間， メ又 3 例平均值 $0.26 \pm 0.01 \mathrm{mg} / 48$ 時間である。 $\mathrm{F}_{4}$ 㳉V分劃でオ久 3 例头 均值は $0.88 \pm 0.03 \mathrm{mg} / 48$ 㭙間， メ久 4 例平均值は $0.86 \pm 0.03 \mathrm{mg} / 48$ 時間，Ul分劃はオ入 3 例平均值 $0.34 \pm$ $0.02 \mathrm{mg} / 48$ 時間，メ又 4 例平均值 $0.41 \pm 0.01 \mathrm{mg} / 48$ 時間である。. $F_{5}$ で洨U分劃文，オス 3 例平均值 0.92 上

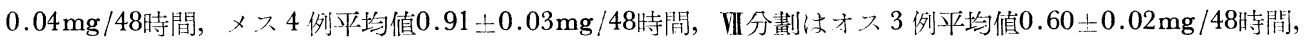

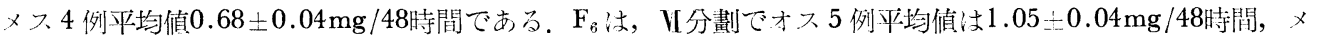
大 4 例平均值は $1.11 \pm 0.06 \mathrm{mg} / 48$ 㭙間, UII分劃オス 5 例平均值は $0.69 \pm 0.07 \mathrm{mg} / 48$ 時間， メ久 4 例平均值は

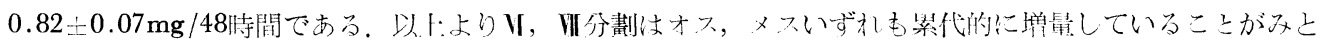
多ら机子。

\section{（3） 尿中 17-OHCS 測定成績}

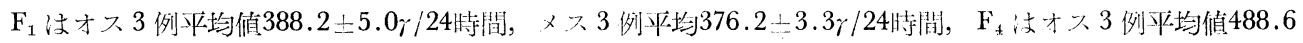

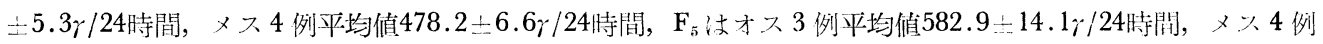
平均值 $578.5 \pm 14.07 \gamma / 24$ 時間, $\mathrm{F}_{6}$ 汶才入 5 例平均值 $771.6 \pm 14.45 \gamma / 24$ 㭙間, メ> 4 例平均值 $792.5 \pm 16.1 \gamma / 24$

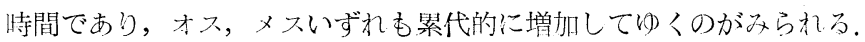

\section{（4）尿中ウロペプシン測定成績}

$\mathrm{F}_{1}$ で注凝乳能法でオス 3 例平均值は $2.79 \pm 0.11 \mathrm{mg} / 24$ 特間, 又又 3 例平均值㳉 $3.25 \pm 0.41 \mathrm{mg} / 24$ 㭙間, 蛋

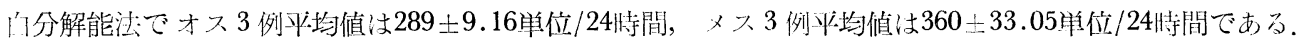

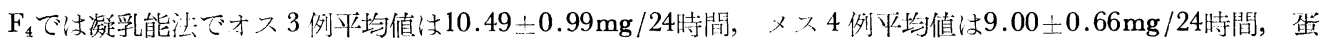
白分解能法でオス 3 例平均值は $1077 \pm 72.26$ 単位/24時間, メ又 4 例平均值は1037 127.09 単位/24時間であ

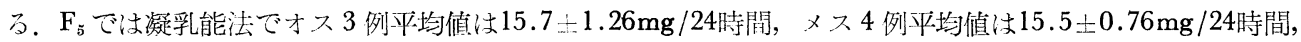
蛋白分解能法でオス 3 例平均值仗 $1535.5 \pm 112.2$ 単位 $/ 24$ 時間, メ又 4 例平均值は $1691 \pm 162.4$ 単位 $/ 24$ 時間で

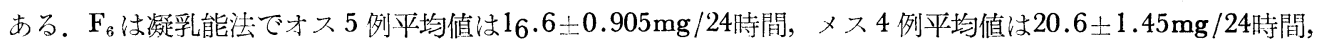
蛋白分解能法でオス 5 例平均值は $2020 \pm 99.74$ 単位/ 24 時間， メ ス 4 例平均值は $1867 \pm 92.86$ 単位 $/ 24$ 時間であ

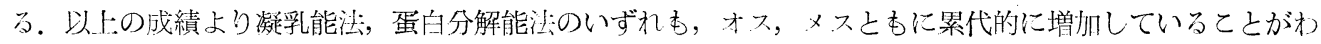
加。

\section{（5）尿中ゴナドトロピン測定成績}

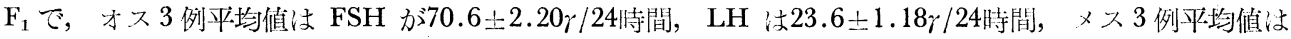

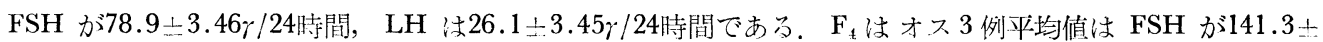
$10.15 \gamma / 24$ 時間, LH が30.8 $\pm 2.90 \gamma / 24$ 時間，又> 4 例平均值は FSH が $142.9 \pm 7.07 \gamma / 24$ 時間， LH は35.9

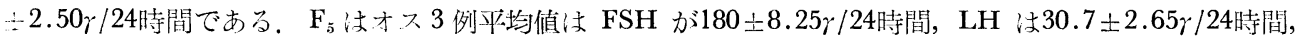

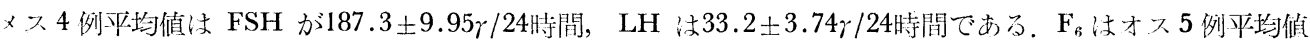
法 FSH が230.0 $\pm 8.0 \% / 24$ 㭙間, LH 


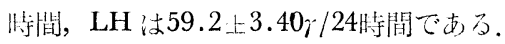

以上から，FSH，LH いずれもオス，メスともに䒺代的に増加しているこよがわから。

$2 \mathbf{F}_{5}, \mathbf{F}_{6}$ ウサギの生後日数による変動（第 7,8 表, 第 8,9 図）

各代ともオス，メス 3 例ずつをとり，生後50日より測定した。

\section{（1）尿中 17-KS 総量測定成績}

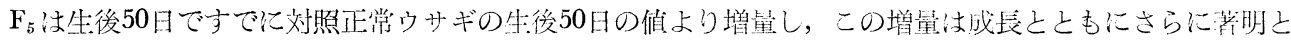
なり生後120日前後において両者の差は最も大きくなる。 また生後120日前後において F $_{5}$ 成熟時の值に一致

第 7 表 甲本投与学孫 $\mathrm{F}_{\text {。 }}$ ウサギの生後日数と尿中 17-KS 総量，17-KS 分劃，17-OHCS， ウロペプシン，ゴナドトロピン排帮值（平均值）

\begin{tabular}{|c|c|c|c|c|c|c|c|c|c|c|c|c|c|c|}
\hline \multirow{2}{*}{$\begin{array}{l}\text { 生後 } \\
\text { 日数 } \\
(\mathrm{H})\end{array}$} & \multirow[b]{2}{*}{ 性 } & \multirow{2}{*}{$\begin{array}{c}17-\mathrm{KS} \\
\text { 総量 } \\
(\mathrm{mg} / 48 \mathrm{~h})\end{array}$} & \multicolumn{7}{|c|}{ 17-KS 分劃 } & \multirow{2}{*}{$\begin{array}{c}17- \\
\text { OHCS } \\
(\gamma / 24 \mathrm{~h})\end{array}$} & \multicolumn{2}{|c|}{$\begin{array}{c}\text { ロペプミン } \\
(/ 24 \mathrm{~h})\end{array}$} & \multicolumn{2}{|c|}{$\begin{array}{l}\text { ゴナドトロ } \\
\text { ン }(\gamma / 24 \mathrm{~h})\end{array}$} \\
\hline & & & I & $\|$ & III & $\mathrm{IV}+\mathrm{V}$ & VI & VII & VII & & $\begin{array}{c}\text { 凝乳能 } \\
(\mathrm{mg})\end{array}$ & $\begin{array}{l}\text { 蛋 } 16 \\
\text { 分解能 } \\
\text { (nnit) }\end{array}$ & $\mathrm{FSH}$ & $\mathrm{LH}$ \\
\hline \multirow{2}{*}{50} & $\hat{\delta}$ & 0.90 & 0.08 & 0.13 & 0.02 & 0.26 & 0.28 & 0.08 & 0.05 & 115 & 0.24 & 20 & 20 & 8.3 \\
\hline & 우 & 0.84 & 0.07 & 0.13 & 0.01 & 0.25 & 0.28 & 0.06 & 0.04 & 106 & 0.27 & 17 & 21.0 & 8.0 \\
\hline \multirow[t]{2}{*}{60} & $\hat{\delta}$ & 0.91 & & & & & & & & 115.3 & 0.26 & 25 & 26.5 & 10.2 \\
\hline & 오 & 0.90 & & & & & & & & 116 & 0.27 & 20 & 26.0 & 11.0 \\
\hline \multirow[t]{2}{*}{70} & $\hat{\delta}$ & 1.26 & 0.10 & 0.15 & 0.18 & 0.33 & 0.35 & 0.10 & 0.05 & 126 & 0.35 & 42.0 & 39.0 & 16.0 \\
\hline & 우 & 1.25 & 0.11 & 0.14 & 0.17 & 0.34 & 0.34 & 0.09 & 0.06 & 129 & 0.30 & 40.5 & 37.6 & 15.2 \\
\hline \multirow[t]{2}{*}{80} & $\hat{\jmath}$ & 1.36 & & & & & & & & 137 & 1.20 & \begin{tabular}{|l|}
59.0 \\
\end{tabular} & 42.0 & 18.2 \\
\hline & 우 & 1.28 & & & & & & & & 139 & 1.10 & 66.2 & 39.6 & 17.0 \\
\hline \multirow{2}{*}{90} & $\hat{\delta}$ & 1.79 & 0.11 & 0.14 & 0.24 & 0.57 & 0.40 & 0.23 & 0.10 & 172 & 3.44 & 300 & 74.0 & 22.0 \\
\hline & 우 & 1.55 & 0.10 & 0.15 & 0.23 & 0.37 & 0.39 & 0.22 & 0.09 & 170 & 3.10 & 256 & 80.2 & 21.0 \\
\hline \multirow[t]{2}{*}{100} & $\hat{\delta}$ & 2.34 & 0.11 & 0.17 & 0.26 & 0.79 & 0.60 & 0.29 & 0.12 & 285 & 6.0 & 586 & 136.0 & 23.0 \\
\hline & 우 & 2.11 & 0.11 & 0.15 & 0.30 & 0.49 & 0.66 & 0.27 & 0.13 & 305 & 6.2 & 472 & 152.2 & 21.5 \\
\hline \multirow[t]{2}{*}{110} & $\hat{o}$ & 3.10 & & & & & & & & 420 & 12.0 & 820 & 162.2 & 25.5 \\
\hline & 우 & 3.09 & & & & & & & & 412 & 12.4 & 910 & 170.0 & 27.0 \\
\hline \multirow[t]{2}{*}{120} & $\hat{\delta}$ & 3.72 & 0.12 & 0.21 & 0.32 & 1.28 & 0.90 & 0.62 & 0.27 & 580.2 & 15.0 & 1430 & 182.0 & 30.0 \\
\hline & 우 & 3.35 & 0.09 & 0.21 & 0.40 & 0.80 & 0.97 & 0.60 & 0.28 & 578.0 & 15.5 & 1650 & 187.3 & 33.0 \\
\hline \multirow[t]{2}{*}{130} & $\hat{o}$ & 3.70 & & & & & & & & 580.0 & 15.6 & 1500 & 190 & 31.0 \\
\hline & 오 & 3.31 & & & & & & & & 581.0 & 16.0 & 1620 & 188.0 & 32.5 \\
\hline \multirow[t]{2}{*}{150} & $\hat{\jmath}$ & 3.68 & 0.10 & 0.20 & 0.30 & 1.30 & 0.93 & 0.60 & 0.25 & 572.1 & 14.9 & 1410 & 191 & 32.0 \\
\hline & 우 & 3.25 & 0.08 & 0.15 & 0.35 & 0.71 & 0.88 & 0.84 & 0.24 & 570.0 & 15.0 & 1510 & 193.5 & 31.5 \\
\hline \multirow[t]{2}{*}{180} & $\hat{\delta}$ & 3.70 & & & & & & & & 570 & 14.0 & 1400 & 190 & 33.0 \\
\hline & 오 & 3.22 & & & & & & & & 572 & 16.0 & 1520 & 193.0 & 30.0 \\
\hline \multirow[t]{2}{*}{210} & $\hat{\jmath}$ & 3.66 & 0.11 & 0.20 & 0.30 & 1.27 & 0.90 & 0.60 & 0.28 & 576 & 15.1 & 1510 & 192.0 & 32.0 \\
\hline & 우 & 3.26 & 0.09 & 0.15 & 0.35 & 0.71 & 0.89 & 0.83 & 0.24 & 560 & 15.1 & 1480 & 189.2 & 33.5 \\
\hline \multirow[t]{2}{*}{300} & $\hat{\jmath}$ & 3.67 & 0.12 & 0.20 & 0.30 & 1.27 & 0.90 & 0.61 & 0.27 & 581.0 & 14.0 & 1470 & 195.0 & 30.1 \\
\hline & 우 & 3.30 & 0.12 & 0.18 & 0.47 & 0.74 & 0.90 & 0.55 & 0.34 & 562.0 & 14.2 & 1300 & 182.0 & 35.5 \\
\hline
\end{tabular}

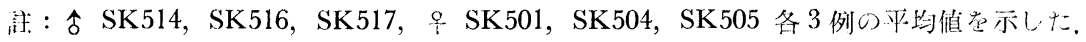


第 8 表 川未投与子孫 $\mathrm{F}_{6}$ ウサギの生後日数之尿州 17-KS 総最, 17- KS 分劃, 17- OHCS, ウロペプシレ，ゴナドトロピン排淤做（性做）

\begin{tabular}{|c|c|c|c|c|c|c|c|c|c|c|c|c|c|c|}
\hline \multirow{2}{*}{$\begin{array}{l}\text { 生後 } \\
\text { H数 } \\
\text { (H) }\end{array}$} & \multirow{2}{*}{ 性 } & \multirow{2}{*}{$\begin{array}{c}\begin{array}{c}17-\mathrm{KS} \\
\text { 総量 } \\
(\mathrm{mg} / 48 \mathrm{~h})\end{array}\end{array}$} & \multicolumn{7}{|c|}{ 17-KS 分劃 } & \multirow{2}{*}{$\begin{array}{c}17- \\
\text { OHCS } \\
(\gamma / 24 h)\end{array}$} & \multicolumn{2}{|c|}{$\begin{array}{c}\text { ウロペヂシン } \\
\text { (/24h) }\end{array}$} & \multicolumn{2}{|c|}{$\begin{array}{l}\text { ゴナドトロ } \\
\text { ン }(r / 24 h)\end{array}$} \\
\hline & & & $\mathrm{I}$ & II & III & $\mathrm{I}+\mathrm{V}$ & VI & VII & VIII & & 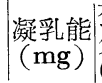 & $\begin{array}{l}\text { 蛋盼 } \\
\text { (nnit) }\end{array}$ & FSH & LH \\
\hline \multirow[t]{2}{*}{50} & $\hat{o}$ & 0.92 & 0.08 & $\mid 0.13$ & 0.03 & 0.26 & 0.29 & 0.08 & 0.05 & 115 & 0.25 & 20 & 20 & 8.5 \\
\hline & 우 & 0.84 & 0.07 & 0.12 & 0.01 & 0.25 & 0.28 & 0.07 & 0.04 & 105 & 0.28 & 15 & 21.0 & 8.2 \\
\hline \multirow[t]{2}{*}{60} & $\hat{o}$ & 0.93 & & & & & & & & 12 & 0.30 & 30 & 26.0 & 11.0 \\
\hline & 우 & 0.91 & & & & & & & & 121.2 & 0.41 & 27 & 25.7 & 11.0 \\
\hline \multirow[t]{2}{*}{70} & $\hat{o}$ & 1.28 & 0.10 & 0.15 & 0.17 & 0.33 & 0.37 & 0.12 & 0.04 & 130 & 0.70 & 50 & 42 & 15.0 \\
\hline & 우 & 1.34 & 0.11 & 0.14 & 0.18 & 0.35 & 0.39 & 0.10 & 0.07 & 142 & 0.65 & 54.0 & 40.0 & 17.0 \\
\hline \multirow[t]{2}{*}{80} & $\hat{\delta}$ & 1.50 & & & & & & & & tol & 1.51 & 82 & 81.0 & 20.0 \\
\hline & 우 & 1.42 & & & & & & & & 172 & 2.00 & 95 & 85.2 & 21.1 \\
\hline \multirow[t]{2}{*}{90} & $\hat{o}$ & 1.95 & 0.11 & 0.15 & 0.25 & 0.59 & 0.50 & 0.25 & 0.10 & 2 & 4.01 & 250 & 102.1 & 23.0 \\
\hline & 우 & 1. & 0.11 & 0.15 & 0.23 & 0.37 & 0.41 & 0.30 & 0.10 & 190 & 5.21 & 310 & 110.0 & 25.5 \\
\hline \multirow[t]{2}{*}{100} & $\hat{\delta}$ & & & 0.18 & 0.26 & 0.80 & 0.70 & 35 & & & 7.90 & 630 & 166.2 & 26.0 \\
\hline & 우 & 2.34 & 0.11 & 0.16 & 0.31 & 0.50 & 0.72 & 0.40 & 0.14 & 287 & 8.00 & 570 & 170.0 & 29.0 \\
\hline \multirow[t]{2}{*}{110} & $\hat{\delta}$ & 3.40 & & & & & & & & & 7.00 & 1100 & 10.0 & 35.0 \\
\hline & 우 & 3.36 & & & & & & & & 10 & 15.50 & 1200 & 191.0 & 47.2 \\
\hline \multirow[t]{2}{*}{120} & $\hat{\delta}$ & & 2 & 0.21 & 0 & & 1.15 & .70 & .25 & & 1.0 & 2100 & 238.0 & 60.0 \\
\hline & $q$ & 84 & 3 & 0.20 & 0.42 & 82 & 1.10 & 0.83 & 34 & .0 & 20.1 & 1920 & 241.0 & 59.0 \\
\hline \multirow[t]{2}{*}{130} & $\hat{o}$ & & & & & & & & & 0.6 & 19.0 & 2000 & 240.2 & 68.5 \\
\hline & 오 & 3.51 & & & & & & & & 766 & 18.5 & 1790 & 250 & 62.0 \\
\hline \multirow{2}{*}{150} & $\hat{\delta}$ & 3.97 & 0.13 & 0.20 & 0.33 & 1.29 & 1.10 & $\mid 0.67$ & 0.25 & 765 & 21.0 & 2200 & 235.6 & 52.0 \\
\hline & 우 & 3.78 & 0.10 & 0.20 & 0.41 & 0.80 & 1.10 & 0.83 & 0.34 & 780 & 19.0 & 1900 & 250.0 & 63.5 \\
\hline \multirow[t]{2}{*}{180} & $\hat{\delta}$ & 3.89 & & & & & & & & 800 & 19.8 & 1980 & 240 & 51.0 \\
\hline & 우 & 3.67 & & & & & & & & 815 & 20.3 & 1950 & 260 & 60.0 \\
\hline \multirow[t]{2}{*}{210} & $\hat{\delta}$ & 4.00 & 0.13 & 0.22 & 0.32 & 1.30 & 1.00 & $\mid 0.69$ & $\mid 0.24$ & 780 & 20.6 & 2050 & 250 & 62.0 \\
\hline & To & 3.78 & 0.10 & 0.20 & 0.41 & 0.80 & 1.10 & 0.83 & 0.34 & 790.2 & 21 & 1830 & 231 & 50.0 \\
\hline \multirow[t]{2}{*}{230} & 全 & 3.83 & 0.12 & 0.21 & 0.30 & 1.30 & 0.99 & $\mid 0.68$ & 0.23 & 762 & 20 & 1950 & 235 & 50.0 \\
\hline & 웅 & 3.52 & 0.12 & 0.19 & 0.40 & 0.80 & 1.00 & 0.71 & 0.30 & 767 & 19 & 1790 & 232.1 & 53.5 \\
\hline
\end{tabular}

註：令 SK602，SK610，SK613，ㅇ SK601，SK616，SK617 各 3 例の平均值を示した。

し，忈の後む増量は維持されている。

$\mathrm{F}_{6}$ では $\mathrm{F}_{5}$ よりさらに增量は著しく，关れ恃生後50日より明らかにみ上められる。

以上の変化泣オス，メスと五同様の傾向を示している。

\section{(2) 尿中 17-KS 分劃測定成績}

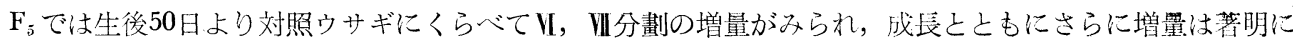
なり生後100日前後において急激に增加し，120日頃に成熟時の值となり，その後も增量を維持しているが， 生後200日前後においてやや減少の傾向を示すあの屯みられた。 
第 8 図川未投与子孫 $\mathrm{F}_{5}, \mathrm{~F}_{6}$ ウサギの生後目数し尿州 $17-\mathrm{KS}$ ，

17-OHCS, ゴナドトロピンの変動
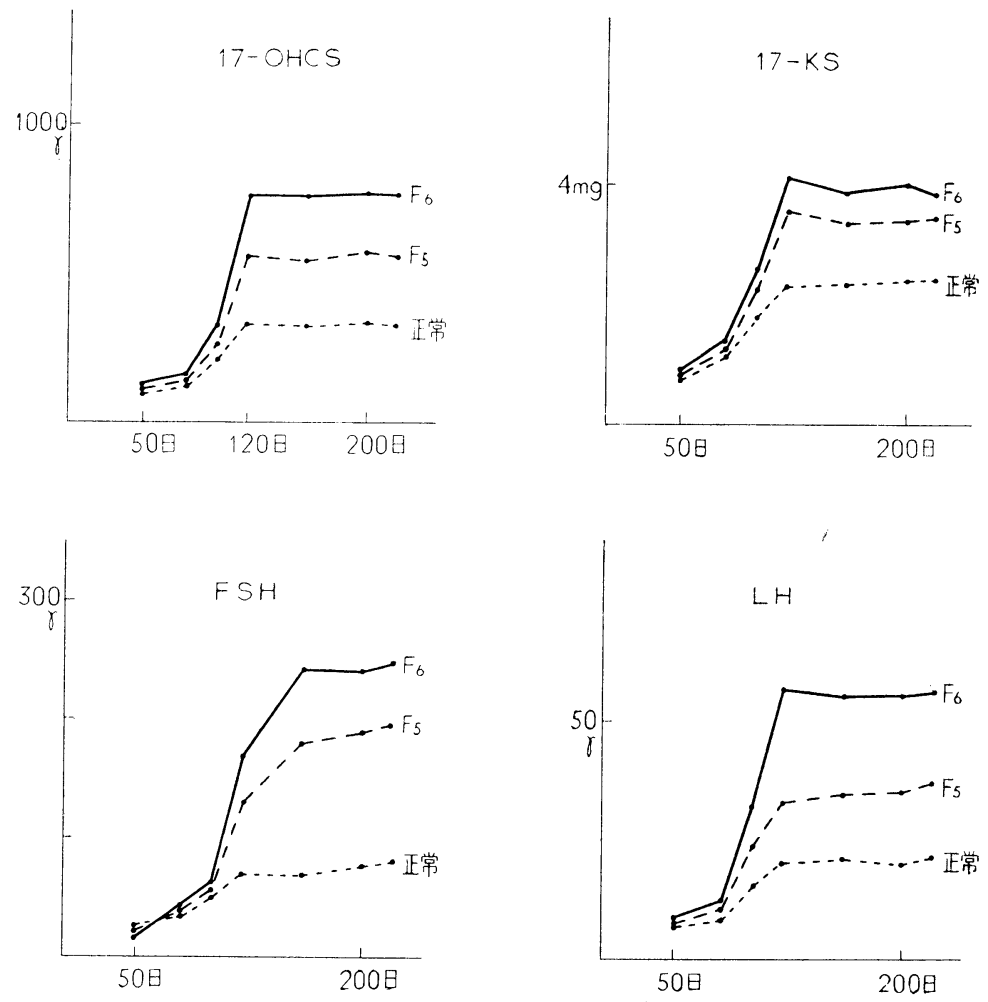

- $F_{6}(\hat{s} 3$ 例平均値)

$----F_{5}(\hat{8} 3$ 例平均檤)

……正常( $(5$ 例巫均値)

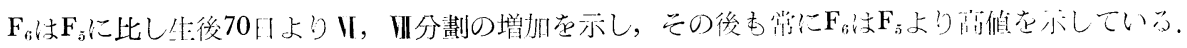

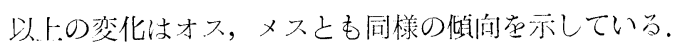

\section{（3）尿中 17-OHCS 測定成績}

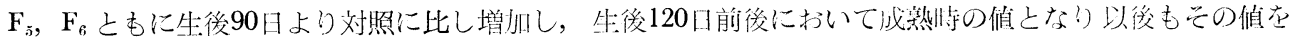

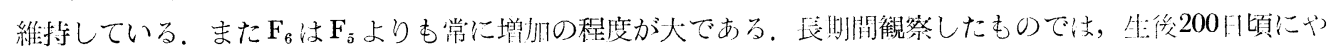
や減少の傾问を示守ものあみられた。

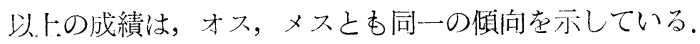

\section{(4) 尿中ウロペプシン測定成績}

$\mathrm{F}_{5}, \mathrm{~F}_{6}$ と6に生後 50 日より対照に比し増量を示し生後 90 日前後に急激に增加し，生:後120日頃に成熟㭙り

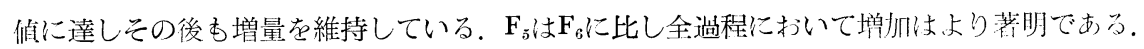

以上の変化はオス，メ久とも同様の傾向を示している。

\section{（5）尿中ゴナドトロピン測定成績}

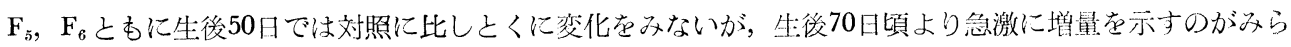
れる，F。注生後80日で対照の1.5倍に増加し，90日で 2 倍となり生後120日では2.6倍となり成熟特の值に洼 しその後も増量を維持している， $F_{6}$ で注生後70日で対照の1.5倍となり，80日では2.8傜となり，以後はさら

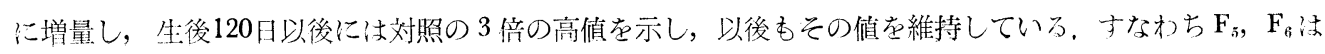




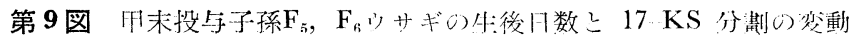
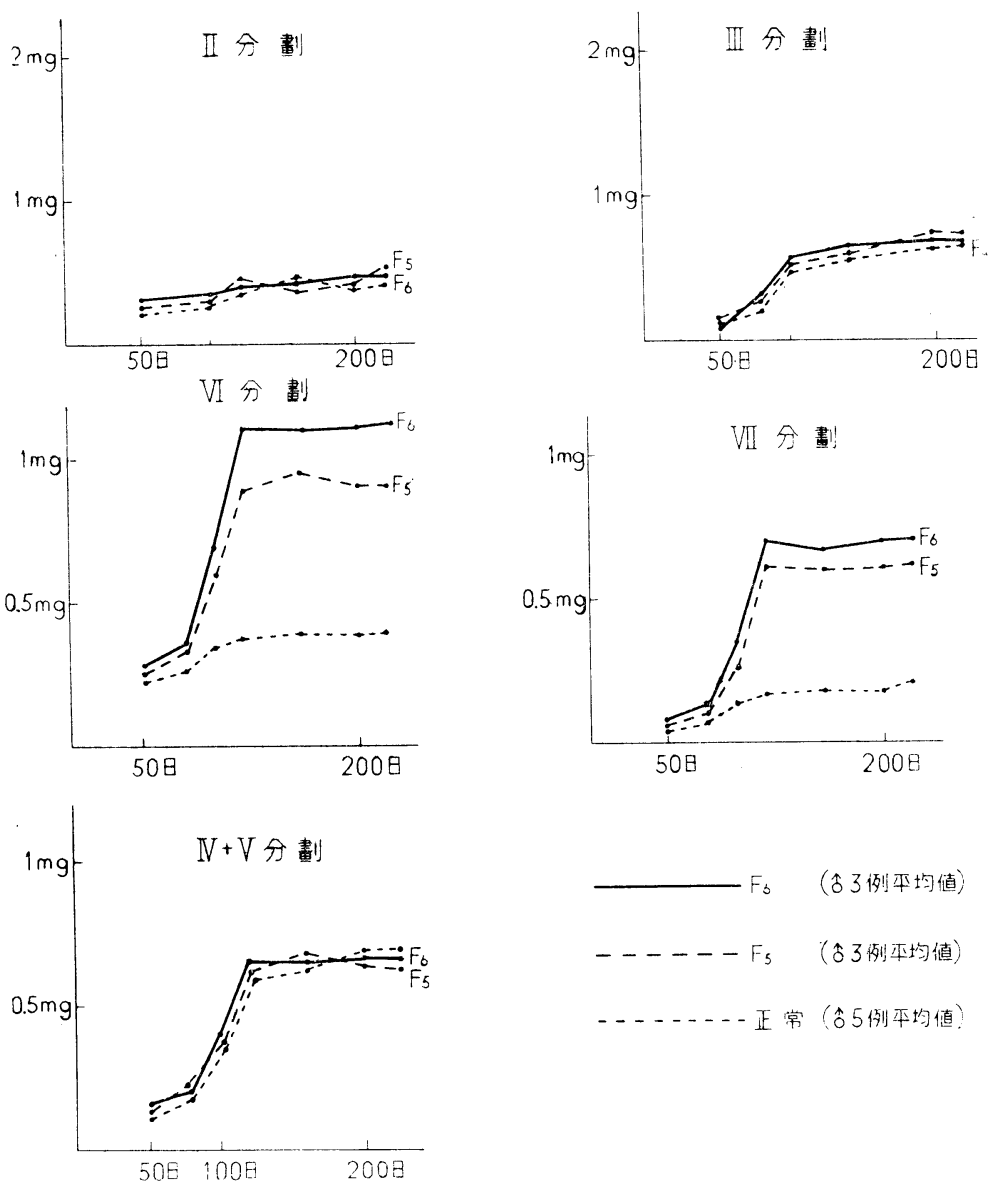

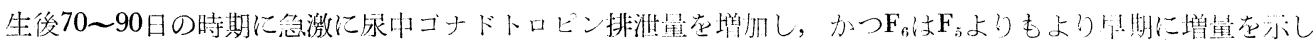
ている。以上はオス，メスとも同様の傾向在示している。この成績を 17-KS，17-OHCS，ウロペプシンの成 績と比べてみると，尿中ゴナドトロピンはト記の副腎皮啠ホルモンおよでその関係物犋よりもやや生後日数 の早い時期に増量が著明になるこよがうかがわれる。こ机よくに $\mathrm{F}_{6}$ において明らかである。また生後 120 日以後の経過をみると尿中ゴナドトロピンは生後200日前後まで若干の増加を示す上うであるが，副腎皮所

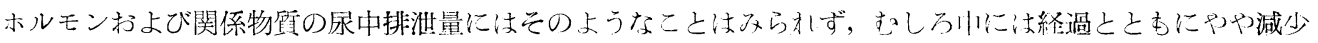
してゆく傾们在示すものもみられた。

第 3 節 歴代甲摘子孫ウサギ $\left(F_{1}, F_{4}\right)$ (第 9 表)

成熟時の測定成績はつぎのようであろ.

\section{（1）尿中 17-KS 総量測定成績}

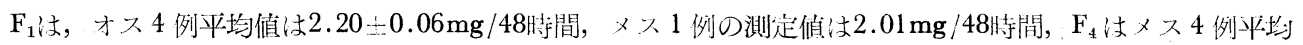

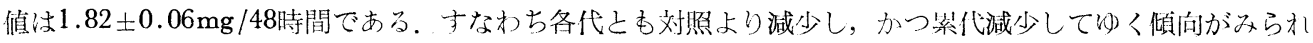
万。

\section{（2）尿中 17-KS 分劃測定成績}

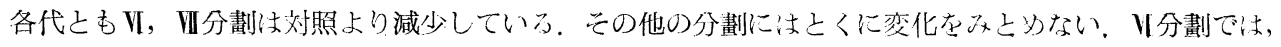


第 9 表 刖摘子孫りサギの㽷中 17-KS 総量，17-KS 分劃，17-OHCS，ウロくンシン， ゴナドトロピン排泄值 (平均值)

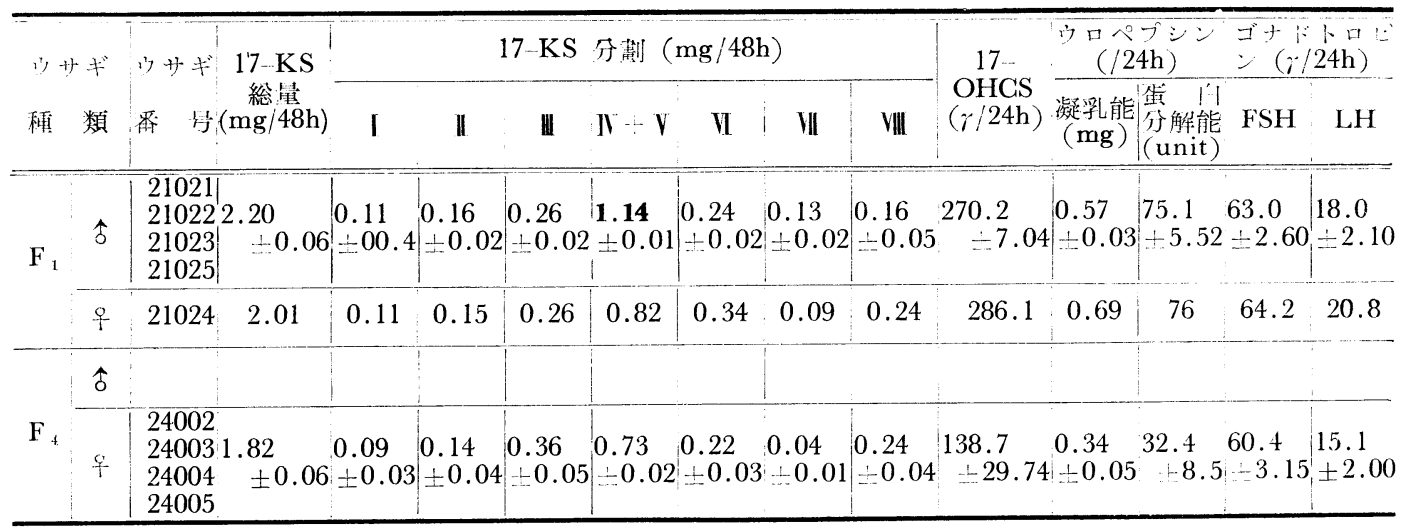

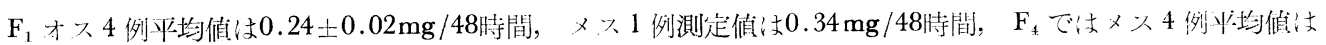

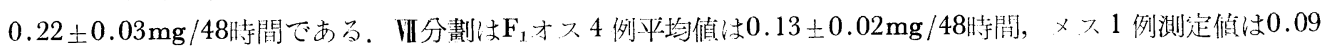

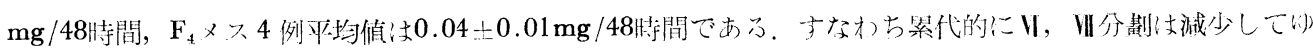
く倾问がひられる。

\section{(3) 尿中 17-OHCS 測定成績}

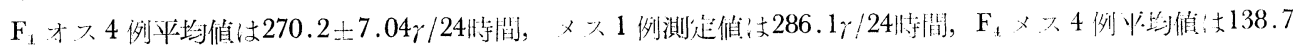

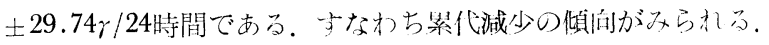

\section{(4) 尿中ウロペブシン}

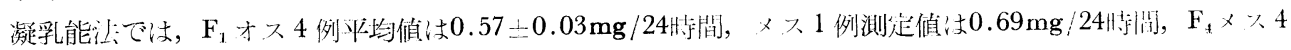

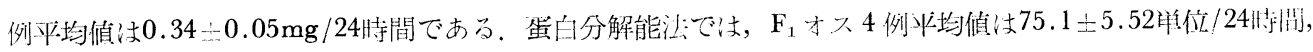

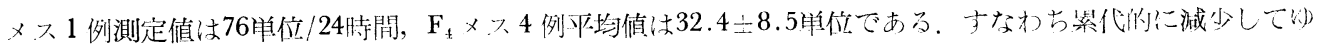
く傾的がみられる。

\section{（5）尿中ゴナドトロピン測定成績}

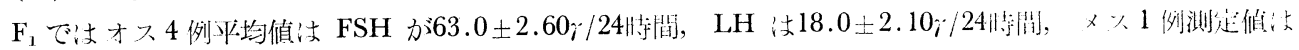

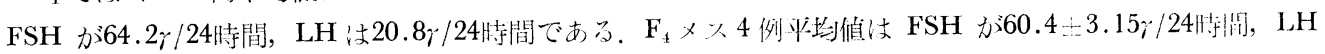

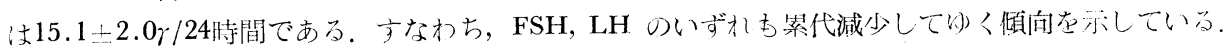

\section{第 4 節 甲末投与ウサギ（第10表）}

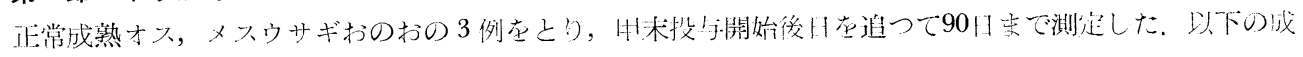
績はオス, メスおのおの 3 例の平均值でポした。

\section{（1）尿中 17-KS 総量測定成績}

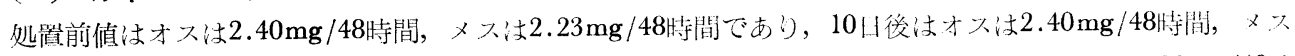

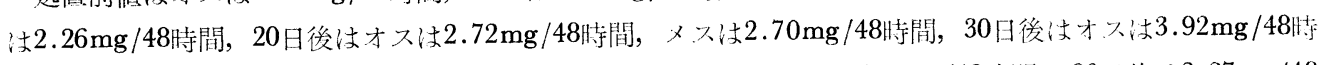
間，メ又㳉 $3.83 \mathrm{mg} / 48$ 時間，60日後仗入は $3.15 \mathrm{mg} / 48$ 㭙間，メ又注 $3.0 \mathrm{mg} / 48$ 侍間，90内後は $2.27 \mathrm{mg} / 48$

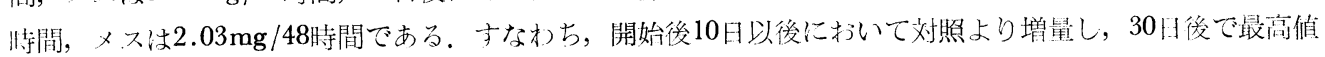

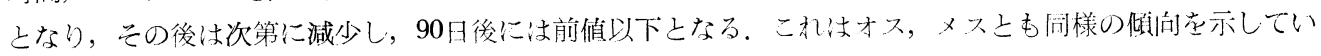
今.

\section{（2）尿中 17-KS 分劃测定成績}

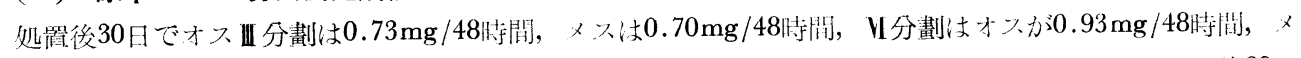

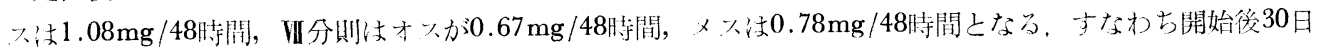


第10表 甲末末投与ウサギの尿中 17 - KS 総量ならごに分剒，17 OHCS， ウロペプシン，ゴナドトロピン排淮佔

\begin{tabular}{|c|c|c|c|c|c|c|c|c|c|c|c|c|c|}
\hline \multirow{2}{*}{ 経過历l数 } & \multirow{2}{*}{$\begin{array}{c}17-\mathrm{KS} \\
\text { 総量 } \\
(\mathrm{mg} / 48 \mathrm{~h})\end{array}$} & \multicolumn{7}{|c|}{ 17-KS 分劃 ( $\mathrm{mg} / 48 \mathrm{~h})$} & \multirow{2}{*}{$\begin{array}{c}17- \\
\text { OHCS } \\
(\gamma / 24 h)\end{array}$} & \multicolumn{2}{|c|}{$\begin{array}{c}\text { ウロペプシン } \\
(/ 24 \mathrm{~h})\end{array}$} & \multicolumn{2}{|c|}{$\begin{array}{l}\text { ゴナドトロட゚ } \\
\text { ン }(\gamma / 24 h)\end{array}$} \\
\hline & & I & II & III & $\mathrm{N}+\mathrm{V}$ & VI & VII & VIII & & $\mid \begin{array}{c}\text { 凝乳能 } \\
(\mathrm{mg})\end{array}$ & $\begin{array}{l}\text { 复息解解 } \\
\text { (nnit) }\end{array}$ & FSH & $\mathrm{LH}$ \\
\hline \multirow[t]{2}{*}{ 処置前值 } & 今 2.40 & 0.10 & 0.17 & 0.27 & 1.15 & 0.36 & 0.18 & 0.17 & 295 & 0.95 & 105 & 69.6 & 19.2 \\
\hline & 우 2.23 & 0.10 & 0.15 & 0.38 & 0.73 & 0.46 & 0.15 & 0.26 & 290 & 0.92 & 96 & 63.2 & 21.0 \\
\hline \multirow{2}{*}{5 日 } & 今ิ 2.42 & & & & & & & & 315 & & & & \\
\hline & 우 2.20 & & & & & & & & 302 & & & & \\
\hline \multirow{2}{*}{ 10日 } & 今 2.40 & & & & & & & & 355 & 3.20 & 400 & 80.2 & 30.0 \\
\hline & 우 2.26 & & & & & & & & 348 & 3.00 & 370 & 76.2 & 26.5 \\
\hline \multirow[t]{2}{*}{ 15日 } & 今 2.50 & & & & & & & & 410 & & & & \\
\hline & 우 2.30 & & & & & & & & 400 & & & & \\
\hline \multirow{2}{*}{$20 \mathrm{H}$} & 今 2.72 & & & & & & & & 560 & 10.5 & 1200 & 125.5 & 35.0 \\
\hline & 우 2.70 & & & & & & & & 552 & 12.0 & 1120 & 112.0 & 37.2 \\
\hline \multirow{2}{*}{25 日 } & 令 3.30 & & & & & & & & 680 & & & & \\
\hline & 우 3.20 & & & & & & & & 695 & & & & \\
\hline \multirow{2}{*}{30 日 } & 全 3.92 & 0.10 & 0.16 & 0.73 & 1.16 & 0.93 & 0.67 & 0.17 & 772.0 & 18.3 & 1950 & 178.0 & 40.3 \\
\hline & 우 3.83 & 0.10 & 0.17 & 0.70 & 0.80 & 1.08 & 0.78 & 0.20 & 775.2 & 18.0 & 1830 & 189.3 & 37.3 \\
\hline \multirow{2}{*}{50 日 } & 个 3.40 & & & & & & & & 710 & & & & \\
\hline & 우 3.51 & & & & & & & & 703 & & & & \\
\hline \multirow[t]{2}{*}{60 日 } & ิ 3.15 & & & & & & & & 735 & 18.2 & 1500 & 162.0 & 35.5 \\
\hline & 우 3.00 & & & & & & & & 725 & 19.0 & 1430 & 152.0 & 32.0 \\
\hline \multirow[t]{2}{*}{80 日 } & $\hat{o}$ & & & & & & & & 420 & & & & \\
\hline & 우 & & & & & & & & 405 & & & & \\
\hline \multirow[t]{2}{*}{90 日 } & 今ิ 2.27 & 0.11 & 0.16 & 0.25 & 1.14 & 0.30 & 0.15 & 0.16 & 240 & 0.80 & 89 & 69.0 & 18.0 \\
\hline & 우 2.03 & 0.11 & 0.15 & 0.35 & 0.73 & 0.31 & 0.14 & 0.24 & 252 & 0.82 & 90 & 60.1 & 20.0 \\
\hline
\end{tabular}

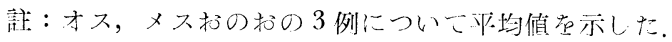

で且分劃 $(\beta-17-\mathrm{KS}), \mathrm{I}, \mathrm{WI}$ 分劃 $(17-\mathrm{oxy}-17-\mathrm{KS})$ は刘照より增量を示している。90日後には, 㸪分劃は才 スが $0.25 \mathrm{mg} / 48$ 時間，メスは $0.35 \mathrm{mg} / 48$ 時間，V分劃はオスか $0.30 \mathrm{mg} / 48$ 時間，メスは0.31 mg/48時間，III

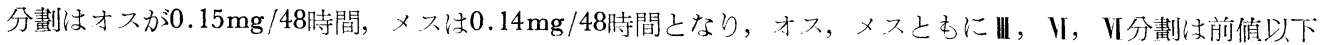
に減少している。

\section{（3） 尿中 17-OHCS 測定成績}

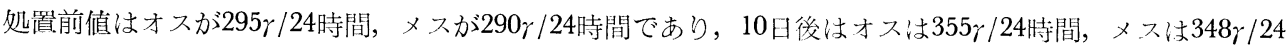

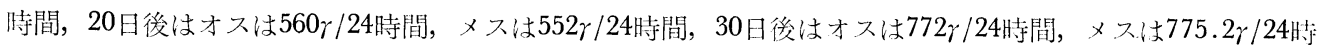

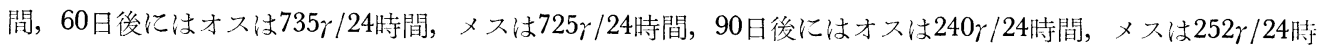
間となる。すなわち，投与開始後 5 日以後に対照より増加し，30日後に最高值となり，以後は次第に減少し 90日後には前值以下となることがわかる，以上注オス，×スとあ同様の傾问を示している。

\section{（4）尿中ウロペプシン測定成績}


凝乳能法では処㯰前值がオスは $0.95 \mathrm{mg} / 24$ 時間，メスは $0.92 \mathrm{mg} / 24$ 時間であり，甲末投与開始後 10 日には オスは $3.20 \mathrm{mg} / 24$ 侍間，メスは $3.00 \mathrm{mg} / 24$ 時間となり，20日後にはオスは $10.5 \mathrm{mg} / 24$ 時間，メス注 $12.0 \mathrm{mg} /$ 24 時間， 30 日後にはオスは $18.3 \mathrm{mg} / 24$ 時間，メスは $18.0 \mathrm{mg} / 24$ 時間，60日後はオスは $18.2 \mathrm{mg} / 24$ 時間，メス は $19.0 \mathrm{mg} / 24$ 時間， 90 日後にはオスは $0.80 \mathrm{mg} / 24$ 時間，メスは $0.82 \mathrm{mg} / 24$ 時間となる。すなわちオス，メス 上む 30 日後に最高值となり以後は次第に減少し，90日後に前值よりやや低い值となる．蛋白分解能法では，

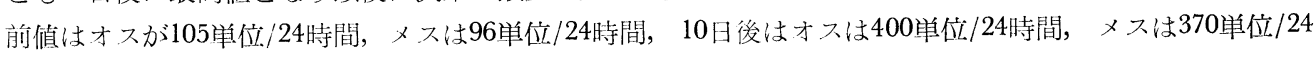
時間，20日後はオスは1200単位/24時間，メ又は1120单位/24時間，30日後はオスは1950単位/24時間，メス は1830単位/24時間，60日後はオスが1500単位/24時間，メスは1430単位/24時間，90日後にはオスが89単位/ 24 時間, メスは90単位/24時間となり, 凝乳能法之同様の経過を示している.

\section{（5）尿中ゴナドトロピン測定成績}

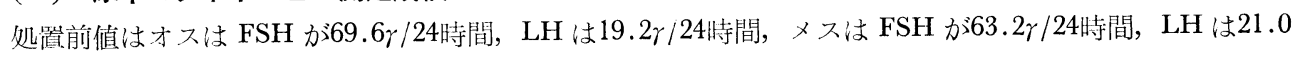
$r / 24$ 時間である。怽投与開始後10日では，才スは FSH かi80.2r/24時間，LH は30.0r/24時間，メスは

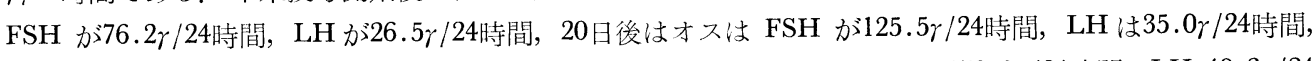
メスは FSH が112r/24時間，LHは37.2r/24時間，30日後はオスは FSH が178.0r/24時間， LH 40.3r/24 壯間，メ又 FSH は189.3r/24時間，LHは37.3r/24時間，60日後は才スは FSH 162.0r/24時間，LH 35.5 $r / 24$ 時間，メスは FSH 152r/24時間，LH 32.0r/24時間，90日後はオスが FSH 69.0r/24時間，LH 18.0 $\gamma / 24$ 時間，×スは FSH 60.1r/24時間，LH 20r/24時間である. すなわちオス，メスとあ，FSH，LH いず 机す投与後10日より増加し，30日頃に最高值となり以後は次第に減少してりき，90日後には前值よりやや低 い值を示すようである。

\section{第 5 節 甲摘ウサギ（第11表）}

正常成熟オス，メスウサギおのおの 3 例に甲摘を行ない，処㯰後日を追つて 90 日まで測定を行なつた。才 ス, メス 3 例についての平均值はつぎのようである.

\section{（1）尿中 17-KS 総量測定成績}

処㯰前值はオスは $2.37 \mathrm{mg} / 48$ 時間，メスは $2.26 \mathrm{mg} / 48$ 侍間であり，10日後仗オスは $2.85 \mathrm{mg} / 48$ 時間，メス は $2.28 \mathrm{mg} / 48$ 時間，20日後はオスは $1.82 \mathrm{mg} / 48$ 時間，メスは $1.93 \mathrm{mg} / 48$ 時間， 30 日後はオスは $1.73 \mathrm{mg} / 48$ 時 間，メスは $1.43 \mathrm{mg} / 48$ 時間，60日後はオスが $1.68 \mathrm{mg} / 48$ 将間，メ又注 $1.30 \mathrm{mg} / 48$ 時間，90日後はオスは 1.62 $\mathrm{mg} / 48$ 時間, メ久注 $1.42 \mathrm{mg} / 48$ 時間である。すなわちオス, メスとも処品後 20 日頃より刘照より減少した值 之なり, 以後も緩慢に減少してゆくようである。

\section{(2) 尿中 17-KS 分劃測定成績}

処真後 30 日では，オスの片分劃は $0.05 \mathrm{mg} / 48$ 時間，メス流 $0.05 \mathrm{mg} / 48$ 時間， II 分劃はオスが $0.13 \mathrm{mg} / 48$ 時 間，メスは $0.17 \mathrm{mg} / 48$ 侍間，U分劃はオスか $0.10 \mathrm{mg} / 48$ 時間，メスは $0.08 \mathrm{mg} / 48$ 時間，UII分劃はオスが 0.03 $\mathrm{mg} / 48$ 時間, メ久は $0.01 \mathrm{mg} / 48$ 時間である。すむおわち II, III, V, UII分劃は刘照に比し減少している。 その 他の分劃にはとくに変化をみと妨な.90日後には，II分劃はオスが $0.06 \mathrm{mg} / 48$ 時間，メスは $0.05 \mathrm{mg} / 48$ 将 間，III分劃はオスが $0.10 \mathrm{mg} / 48$ 時間，メス注 $0.16 \mathrm{mg} / 48$ 時間，V分劃はオスが $0.08 \mathrm{mg} / 48$ 時間，メスは 0.09 $\mathrm{mg} / 48$ 時間，U分劃はオスか $0.02 \mathrm{mg} / 48$ 時間，メスは $0.01 \mathrm{mg} / 48$ 時間である。すなわちオス，メスとも 90 日 後には II, III, VI, III分劃は30日後の值よりさらに若干低い值を示している.

\section{（3）尿中 17-OHCS 測定成績}

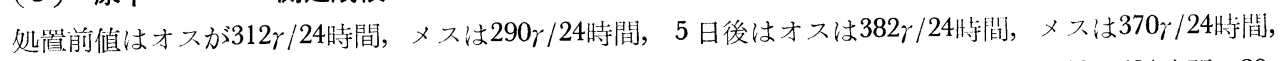

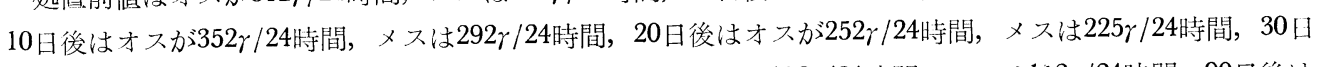

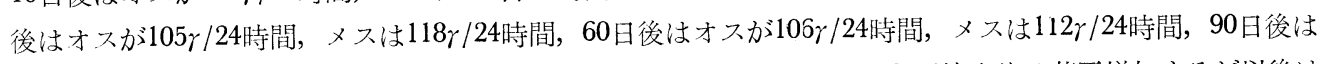

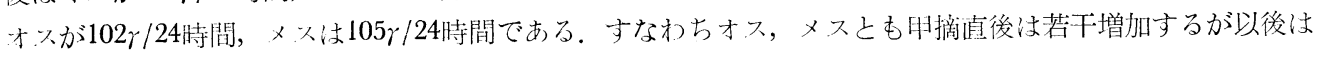
次第に減少してゆくようである。

\section{（4）尿中ウロペプシン測定成績}


第11表 甲摘ウサギの尿中 17--KS 総量ならびに分劃，17-OHCS， ウロペプシン，ゴナドトロピン排泄值

\begin{tabular}{|c|c|c|c|c|c|c|c|c|c|c|c|c|c|}
\hline \multirow[b]{2}{*}{ 経過日数： } & \multirow{2}{*}{$\begin{array}{c}17-\mathrm{KS} \\
\text { 総量 } \\
(\mathrm{mg} / 48 \mathrm{~h})\end{array}$} & \multicolumn{7}{|c|}{ 17-KS 分劃 $(\mathrm{mg} / 48 \mathrm{~h})$} & \multirow{2}{*}{$\begin{array}{c}17- \\
\text { OHGS } \\
(\gamma / 24 \mathrm{~h})\end{array}$} & \multicolumn{2}{|c|}{$\begin{array}{c}\text { ウロペプシン } \\
(/ 24 h)\end{array}$} & \multicolumn{2}{|c|}{$\begin{array}{l}\text { ゴナドトロピ } \\
\text { ン }(r / 24 h)\end{array}$} \\
\hline & & 1 & $\|$ & III & $\mathbf{I V}+\mathrm{V}$ & VI & VII & VIII & & $\begin{array}{c}\left(\begin{array}{c}\text { 凝乳能 } \\
(\mathrm{mg})\end{array}\right. \\
\end{array}$ & $\begin{array}{l}\text { 蛋 } \\
\text { 分解能 } \\
\text { (nnit) }\end{array}$ & $\mathrm{FSH}$ & $\mathrm{LH}$ \\
\hline \multirow{2}{*}{ 処置能值 } & $\hat{\delta} 2.37$ & 0.11 & 0.17 & 0.25 & 1.15 & 0.36 & 0.18 & 0.15 & 312 & 0.91 & 95 & 69.2 & 19.2 \\
\hline & 오 2.26 & 0.10 & 0.15 & 0.38 & 0.75 & 0.47 & 0.15 & 0.26 & 290 & 0.96 & 98 & 66.0 & 21.0 \\
\hline \multirow{2}{*}{ 5日 } & 今 2.37 & & & & & & & & 382 & & & & \\
\hline & ㅇ 2.20 & & & & & & & & 370 & & & & \\
\hline \multirow{2}{*}{10 日 } & 㑒 2.35 & & & & & & & & 352 & 0.88 & 94 & 73.0 & 25.0 \\
\hline & 우 2.28 & & & & & & & & 292 & 0.90 & 90 & 69.8 & 24.0 \\
\hline \multirow{2}{*}{ 15日 } & 今 2.10 & & & & & & & & 220 & & & & \\
\hline & 우 2.00 & & & & & & & & 180 & & & & \\
\hline \multirow{2}{*}{ 20日 } & 今ิ 1.82 & & & & & & & & 252 & 0.52 & 72 & 66.0 & 18.0 \\
\hline & 우 1.93 & & & & & & & & 225 & 0.43 & 63 & 52.0 & 14.3 \\
\hline \multirow{2}{*}{25 日 } & $\hat{\jmath} 1.76$ & & & & & & & & 235 & & & & \\
\hline & 우 1.80 & & & & & & & & 220 & & & & \\
\hline \multirow{2}{*}{ 30日 } & 令 1.73 & 0.10 & 0.05 & 0.13 & 1.14 & 0.10 & 0.03 & 0.18 & 105.0 & 0.25 & 30 & 23.3 & 8.0 \\
\hline & 우 1.43 & 0.11 & 0.05 & 0.17 & 0.78 & 0.08 & 0.01 & 0.23 & 118.0 & 0.23 & 22 & 20.0 & 7.0 \\
\hline \multirow{2}{*}{50 日 } & 全 $1.65^{\prime}$ & & & & & & & & 110 & & & & \\
\hline & 우 1.35 & & & & & & & & 118 & & & & \\
\hline \multirow{2}{*}{60} & $\hat{o} 1.68$ & & & & & & & & 106 & 0.25 & 25 & 18.2 & 6.0 \\
\hline & 우 1.30 & & & & & & & & 112 & 0.20 & 20 & 12.0 & 4.0 \\
\hline \multirow[t]{2}{*}{80 E } & $\hat{o}$ & & & & & & ! & & 110 & & & & \\
\hline & s & & & & & & & & 120 & & & & \\
\hline \multirow{2}{*}{$90 \mathrm{H}$} & 昘 1.62 & 0.08 & 0.06 & 0.10 & 1.13 & 0.08 & 0.02 & 0.15 & 102 & 0.20 & 20 & 12.0 & 6.1 \\
\hline & 우 1.42 & 0.11 & 0.05 & 0.16 & 0.77 & 0.09 & 0.01 & 0.23 & 105 & 0.24 & 22 & 15.3 & 5.2 \\
\hline
\end{tabular}

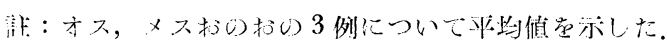

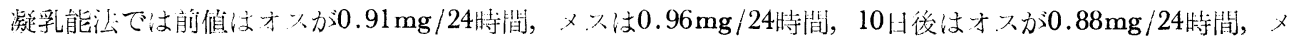
スは $0.90 \mathrm{mg} / 24$ 時間，20日後はオスが $0.52 \mathrm{mg} / 24$ 侍間，メス注 $0.43 \mathrm{mg} / 24$ 時間，30日後はオスが $0.25 \mathrm{mg} / 24$ 特間, メス注 $0.23 \mathrm{mg} / 24$ 特間, 60 日後仗オスか $0.25 \mathrm{mg} / 24$ 時間, メ久は $0.20 \mathrm{mg} / 24$ 時間, 90 日後はオスが

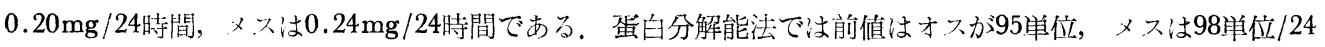

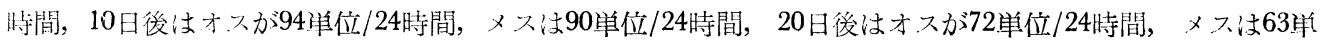

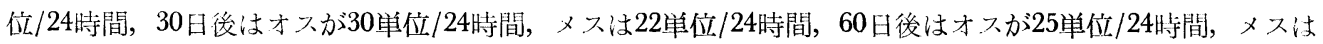

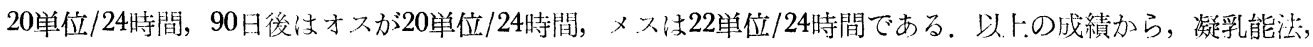

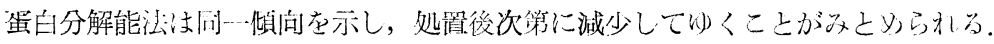

\section{（5）尿中ゴナドトロピン測定成績}

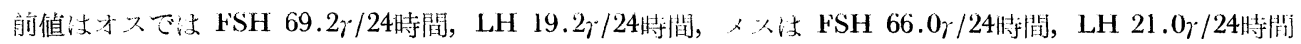

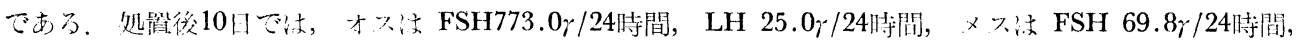




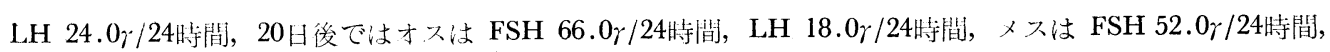
LH 14.3r/24時間，30日後は才スは FSH 23.3r/24時間，LH 8.0r/24時間，メス FSH は20.0 $/ 24$ 時間，

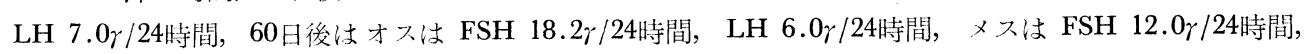

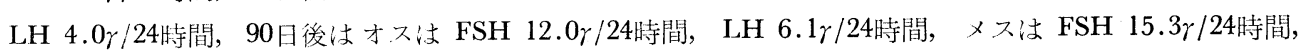
LH 5.2r/24時間である。以上の成績から，FSH，LH とも申摘直後は增加するが，以後は次第に減少して心 き, 90 日後では篗しく低い做在すことがわかる。

\section{第 6 節 測定成績の統計的検定}

以上第 5 節までの測定成績はずシて平均值でホしたが，ここで刘照正常ウサギの測定成績と歴代甲状腺機 能異常子孫りサギの測定成績との間, および磨代甲状腺機能異常子孫りサギ各世代測定成績相互間の有意性

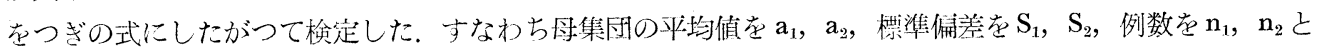
U,

$$
\mathrm{t}=\frac{\overline{\mathrm{a}}_{1}-\overline{\mathrm{a}}_{2}}{\sqrt{\mathrm{n}_{1} \mathrm{~S}_{1}{ }^{2}+\mathrm{n}_{2} \mathrm{~S}_{2}{ }^{2}}} \sqrt{\frac{\mathrm{n}_{1} \mathrm{n}_{2}\left(\mathrm{n}_{1}+\mathrm{n}_{2}-2\right)}{\mathrm{n}_{1}+\mathrm{n}_{2}}}
$$

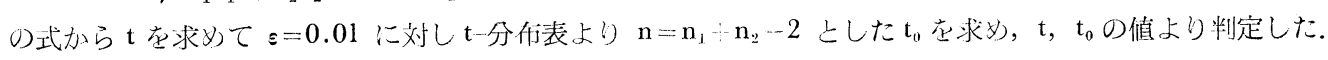
この結果はつぎの通りである。

\section{第 1 項 歴代甲末投与子孫ウサギ（ $\left.F_{1} ， F_{4}, F_{3}, F_{6}\right)$}

\section{（1）尿中 17-KS 総量}

対照正常ウサギの測定成緽との間には， $\mathrm{F}_{1}, \mathrm{~F}_{4}, \mathrm{~F}_{5}, \mathrm{~F}_{6}$ いずれし有意の差があり，また $\mathrm{F}_{1}, \mathrm{~F}_{4}, \mathrm{~F}_{5}, \mathrm{~F}_{6}$ 相不 間にも有意の差をみと》た。

\section{（2）尿中 17-KS 分劃}

$\mathrm{I}$, II, III, IV $+\mathrm{V}$, VIII分劃は対照ウサギと $\mathrm{F}_{1}, \mathrm{~F}_{4}, \mathrm{~F}_{5}, \mathrm{~F}_{6}$ の間および $\mathrm{F}_{1}, \mathrm{~F}_{4}, \mathrm{~F}_{5}, \mathrm{~F}_{6}$ 相血間に有意の差

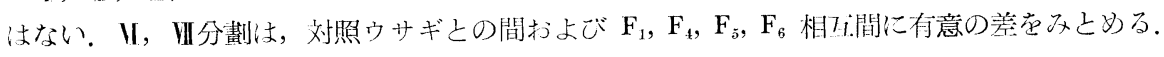

\section{(3) 尿中 17-OHCS}

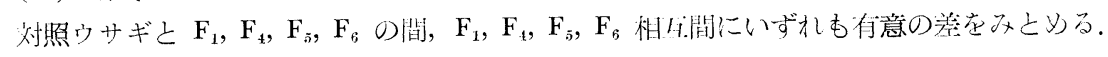

\section{(4) 尿中ウロペプシン}

刘照りサギとの間および $\mathrm{F}_{1}, \mathrm{~F}_{4}, \mathrm{~F}_{5}, \mathrm{~F}_{6}$ 相Fi間に有意の美をみとりる。

\section{(5) 尿中ゴナドトロピン}

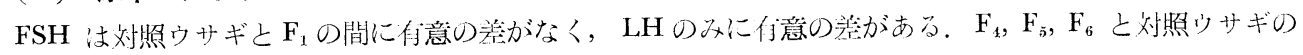
间抄よび $\mathrm{F}_{1}, \mathrm{~F}_{4}, \mathrm{~F}_{5}, \mathrm{~F}_{6}$ 相年.間に㳉 FSH, LH とも付意の差がある。

\section{第 2 項 歴代甲摘子孫ウサギ $\left(\mathrm{F}_{1}, \mathrm{~F}_{4}\right)$}

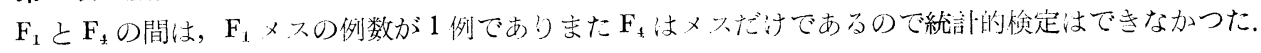

\section{（1）尿中 17-KS 総量}

刘照ウサギと $\mathrm{F}_{1}, \mathrm{~F}_{4}$ の間に有意の登をみとりた。

\section{（2）尿中 17-KS 分劃}

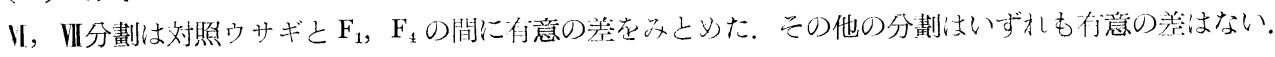

\section{(3) 尿中 17-OHCS}

刘照りサギと $\mathrm{F}_{1}, \mathrm{~F}_{4}$ の間に付意の省がある。

\section{(4) 尿中ウロペプシン}

刘照りサギと $\mathrm{F}_{1}, \mathrm{~F}_{4}$ の間に有意の琴があう。

\section{(5) 尿中ゴナドトロピン}

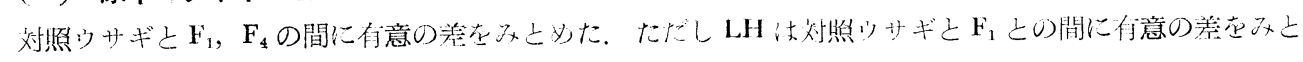
๖なかつた。 
阙本教授の教室において㳊数年前から歴代両覣甲状腺機能異常ウサギより生まれた子係ウサギについて研

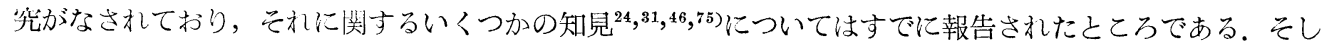
て私は今回とれらウサギについて㽷中 17-KS 総量ならびに分劃, 17-OHCS，ウロペプシン，ゴナドトロピ ンを測定し，また正常りサギおよび甲末投与ウサギ，甲摘ウサギについて同样測定を行なつたので以下それ らの成績について若干の唀祭を加えてみたい上考光る。

(1) 刘照正常ウサギの測定成緽について

17-KS 総量については, 測定方法の項において述ぐたように私は鈴不 ${ }^{67}$, 赫沢 ${ }^{1)}$ の報告に従つて三笔 ${ }^{38}$. Drekter $^{10)}$ ，Pearson ${ }^{5+)} ら の$ J汒で測定を行ない，氏らよよく一致する成績を得た。17-KS 分劃については教

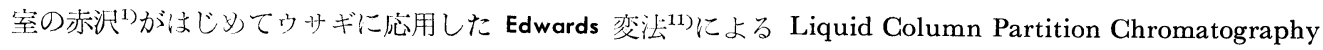
によつて 測定を行ない，測定成績は赤沢の 報告とよく一致することをみとりた。17-OHCS については $\mathrm{Smith}^{63)}$ ，三宅 ${ }^{40)}$ らの方法をウサギに私がはじ文て危用し測定方法に若干の吟味を行ない一定の成績を得た。 赫沢も同様の方法で測定を行ない私の成績とよく一致する成績を得たてとを報告している。ウロペプシンは，

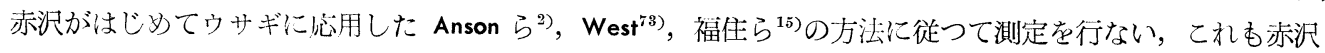
と一致する成績を得ることができた。つぎにゴナドトロピンについては私は Crooke \& Butt9 ${ }^{9}$ の化学的定量 法をウサギに応用し，一定の成績を得ることができた。ウサギについての報告は住かに見当らないが，イヌ

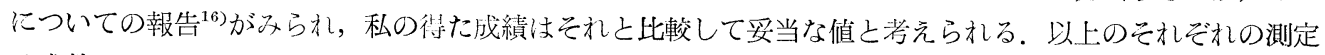
は成熟ウサギのみならず㭃若ウサギについても行ない，成熟する過程における変動を追究し，一定の成緽を 得ることができた，そしてその成績は，17-KS，17-OHCS，ウロペプシンについては鈴木，赤沢の報告とよ く一致しているとと虏みとた。ゴナドトロピンについては他に報告がないが妥当な成績と考える。

(2) 歴代甲末投与子孫ウサギならびに甲未投与ウサギについて

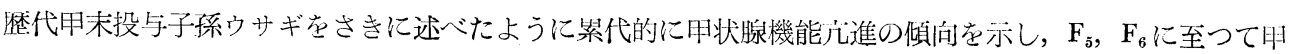
状腺機能九進像を明らかにするに至つている ${ }^{46,75)}$. すなわち， $F_{5}, F_{6}$ 亿至つて先天的に时状腺機能九進像を

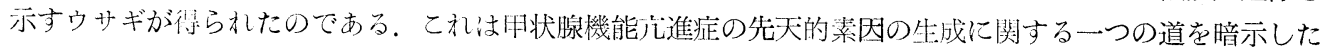
注目すべき知見であると学える。

さて私はこれらウサギについて㽷中 17-KS，17-OHCS，ウロパブシン，ゴナドトロピンを測定したのであ るがその成績はすでに述べたように，いずれあ累代的に增量若示し， $F_{5} ， F_{6}$ 亿至つて著明な增量を示してい

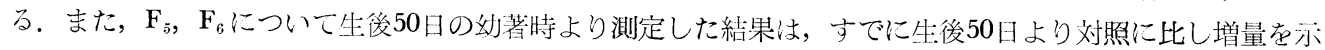
しているのである。すなおち，㲾中 17-KS 総量, 17-KS V, U分劃, 17-OHCS, ウロペプシンがいずれも 增量しているのであり，このことからこれらウサギは生後幼若時より副腎皮筫機能儿進の傾向を示している あのと考元ら礼る。また，永中ゴナドトロピンの増量しているととから，脳下垂体前集に扔方る゙゙ナドト口 ピンの分泌が增版してるものと推定される。

つぎに甲未投与ウサギについてみると，さきに述べたように㞗中 17-KS，17-OHCS，ウロペプシン，ゴ ドトロピンは甲末投与後一時増加するが，云の後はいずれも減少してりく傾向がみられ，長期間増加し続け るということは全くない，17-KS 分劃は，歴代甲未投与子係ウサギとは異なつた像を示し，はじす III，II， 㸪分劃の増加がみられ，その後はそれらが減少してりき90日後に法いずれ屯刘照正常より減少を示している. これらの成績はさきの杫代甲未投与子孫ウサギの成績とはこうとう異なるあのである。すすなわち先大的用状

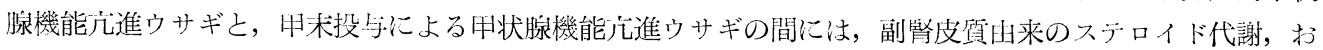
よび脳下垂体前背におけるゴナドトロピンの分泌状態にをうとうのへだたりがあるように考元られる。

さて人体甲状脭機能元進症（バセドり氏病）について氺中 17-KS，17-OHCS，ウロパプシン，コナドトロ

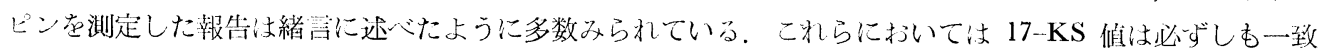

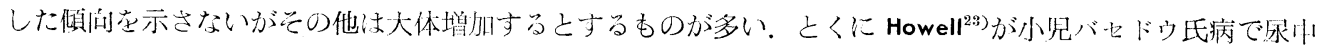


第12表 歴代甲末投与子孫ウサギ，甲末投与ウサギ，人体バセドウ氏病の尿中 17-KS

総量ならびに分劃，17-OHCS，ウロペプシン，ゴナドトロピンの比較

\begin{tabular}{|c|c|c|c|}
\hline & $\begin{array}{l}\text { 歴代甲末投与 } \\
\text { 子孫ウサギ } \\
\end{array}$ & 甲末投 与ウ サギ & $\begin{array}{l}\text { 人体バセドウ氏病 } \\
\text { (甲状腺機能圥進症) } \\
\end{array}$ \\
\hline 17-KS 総量 & 加 & 始め増加し後減少 & 減少, 正常時に増加 \\
\hline 17-KS 分劃 & V, VI分劃増加 & 始め III, VI, VII分劃増加, 後に娍少 & \\
\hline 17-OHCS & 増 & 始め増加し後減少 & 打打むね増加 \\
\hline ウロペプシン & 加 & 始め増加し後減少 & 打打むね増加 \\
\hline ゴナドトロピン & 増 & 始め増加し後減少 & 打打むね増加 \\
\hline
\end{tabular}

ゴナドトロピンが著明に増加している例を報告しているのは注目すべきととと思われる．いま私がウサギに つい得た成績と人体バセドウ氏病についての諸報告をまとめてみると第 12 表に示したようになる。すなわ ち歴代甲末投与子孫ウサギでとくに先天的に甲状腺機能充進像を示すウサギは，その尿中 17-KS，17-OHCS， ウロペプシン，ゴナドトロピンの所見が人体バセドウ氏病のそれとある程度似た傾向を示しているように思 われる．とくに Howell ${ }^{23}$ の小児バセドウ氏病についての報告は，先天的に甲状腺機能六進像を示す歴代甲未 投与子孫 $\mathrm{F}_{5}, \mathrm{~F}_{6}$ ウサギが幼若時より尿中ゴナドトロピンの増量を示すとととよく一致するあのであり, 興味 深く思われる。

人体バセドウ氏病の成因は複雑であり多くの未解決の問題を含んでいるが，とくにその発症が濃厚に先天 的遺伝的因子によると考えられる場合とそうでない場合があるように思われる．したがつて私の歴代甲末投 与子孫ウサギおよび甲未投与ウサギについて得た成績から考えて，人体バセドウ氏病においてその発症機序 の相違によつて尿中ステロイド，ウロペプシン，ゴナドトロピンの排泄状態に差を生ずることはあり得ると 考えられる.すなわち本症のさい尿中のそれらの物質についての成績が完全な一致をみないことの一因はこ のような発症機序の相違にあるのではないかと想像することもできるようである.

(3) 歴代甲摘子孫ウサギならびに甲摘ウサギについて

歴代甲摘子孫ウサギはさきに述べたように累代的に甲状腺機能低下の傾向を示すことが明らかにされてい る。乙れは甲状腺機能充進症について述へたと同様に甲状腺機能低下症の先天的素因生成の一つの道を暗示 する注目すべき知見ではなからうかと考える。私はこれらウサギについて，尿中 17-KS 総量ならびに分劃, 17-OHCS，ウロペプシン，ゴナドトロピンを測定したのであるがその成績はすでに述べたように 17-KS 総 量，17-KS のVI， II 分劃，17-OHCS，ウロペプシン，ゴナドトロピンのいずれむが累代的に減量を示し， $\mathrm{F}_{4}$ ではゴナドトロピンを除きとくに減量している，乙のことから，乙れらウサギは累代その副腎皮質機能は 低下してゆく傾向を示すように考劣られる。 また㽷中ゴナドトロピンが減量していることから，乙れらウサ ギの脳下垂体前葉でのゴナドトロピン分泌が減少しているものと考えられるのである．すなわち歴代甲末投 与子孫ウサギとは逆の変化がみられるわけである.

つぎに甲摘ウサギについてみると，㽷中ステロイド，ゲナドトロピンは甲摘直後は若干増加するあのああ るがその後は次第に減少してゆき，90日後においては対照より著明に減少した值を示している，17-KS 分 劃をみると，30日後にはII， III，V，VI分劃の減量がみられ，90日後にはさらに若干の減量を示している。 この30日以後の所見は歴代甲摘子孫ウサギの所見と似ているが，後者はV， VII分劃（11-oxy-17-KS）のみ減 量しており， II， II 分劃（ $\beta-17-\mathrm{KS})$ にはとくに変化はみられないし，またコナドトロピンの減量があまり 著明でない点が異なつている，以上の所見からみて，歴代甲摘子孫ウサギと甲摘ウサギの間には，尿中の副 腎皮質に由来するステロイドの代謝ならびに脳下垂体におけるゴナドトロピンの分泌状態に若干の相違があ るように思われる。すなわち歴代甲摘子孫りサギ，甲摘りサギはいずれあ副腎皮質の機能低下をきたし，ゴ ナドトロピンの分泌も減少しているようであるがくわしくみると若干の点で相違があるようである。

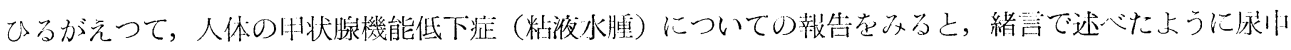
17-KS，17-OHCS，ウロペプシンはいずれもほとんど一致して娍少し，覀中ゴナドトロピンは正常のことが 
第13表 歴代甲摘子孫ウサギ，甲摘ウサギ，人体粘液水腫の尿中 17-KS 総量 ならびに分劃，17-OHCS，ウロペプシン，ゴナドトロピンの比較

\begin{tabular}{|c|c|c|c|}
\hline & 歴代甲摘子孫ウサギ| & 甲 摘 ウ サギ & 人体粘液 水腫 \\
\hline 17-KS 総量 & 減少 & 減 & 娍 \\
\hline 17-KS 分劃 & VI, VII分劃娍少 & I, $\mathbb{H}, \mathrm{VI}, \mathrm{VI}$ 分劃減少 & \\
\hline 17-OHCS & 減＼cjkstart少 & 始めやや増加，後減少 & 減 \\
\hline ウロペプシン & 娍少 & 減＼cjkstart少 & 娍 \\
\hline ゴナドトロピン & やや減少 & 始め増加し後に著減 & 正常またはやや娍少 \\
\hline
\end{tabular}

多く，ときに減少しているようである。乙れを䄳代甲摘子孫ウサギ，甲摘ウサギの所見と比較してみると， 第13表に示したように人体の甲状腺機能低下症（粘液水腫）とは多くの点で一致した傾向がみられるようで あるが，尿中ゴナドトロピンは歴代甲摘子孫ウサギでは甲摘ウサギにみられるほど著明な減少はみられず， 粘液水腫の場合に近いようにも思われる。ささきに述べたように歷代甲摘子孫ウサギと甲摘ウサギの間には尿 中ステロイド，ゴナドトロピンの排泄状態に若干の相違がみられており，乙れらのことから歴代甲摘子孫り サギは甲摘ウサギよりもむしろ人体粘液水腫に似た所見を示すように考元られる。

人体粘液水腫が先天的素因によつて発病することは緒言で述べたように Bernheim ら〕によつて注目されて いるところであり，したがつて歴代甲摘子孫ウサギについての種々の知見は人体粘液水腫の発生病理になん らかの寄与をするあのではないかと考える。

\section{第 5 章 総 括}

歴代両親に甲状腺末（チラジン）を 1 日 $30 \mathrm{mg} / \mathrm{kg}$ あて経口投与を行ない，1 カ月以上してから交配して得 た子孫ウサギ（これらウサギは累代的に甲状腺機能が元進してゆく傾向を示し， $\mathrm{F}_{5}, \mathrm{~F}_{6}$ 亿至つて甲状腺機能 光進像を呈する）の $\mathrm{F}_{1} 6$ 例（オス 3 例，×ス 3 例）， $\mathrm{F}_{4} 7$ 例（オス 3 例，×ス 4 例）， $F_{5} 7$ 例（オス 3 例， $\times>4$ 例)， $\mathrm{F}_{6} 9$ 例 (オフ 5 例，メス 4 例）について，さらにまた歷代両親に甲状腺摘出を行ない 1 カ月以 上してから交配して得た子孫ウサギ（これらウサギは累代的に甲状腺機能が低下してりく傾向を示す）の $\mathrm{F}_{1}$ 5 例（オス 4 例，×ス 1 例)， $\mathrm{F}_{4} 4$ 例（メス 4 例）について成熟時または生後50日から日を追つてその尿中 17-KS 総量ならびに分劃，17-OHCS，ウロペプシン，ゴナドトロピン（FSH，LH）をそれぞれ三宅ら， Drekter, Pearson らの方法, Edwards 変法による Liquid Column Partition Chromatography, Smith ら, 三 完らの方法, West らの方法およびへモグロビン法, Crooke \& Butt の方法で測定し, その結果を正常ウサギ 30 例（オス 15 例，メス 15 例），甲状腺末投与（毎日チラジンを $30 \mathrm{mg} / \mathrm{kg}$ 経口投与）ウサギ 6 例（オス 3 例, ×ス 3 例)，甲状腺摘出ウサギ 6 例（オス 3 例，メス 3 例）の測定成績と此較してつぎの結果を得た.

A 正常（対照）ウサギの成績

(1) 尿中 $17-\mathrm{KS}$ 総量は，オス成熟ウサギでは $2.39 \pm 0.08 \mathrm{mg} / 48$ 時間，メス成熟ウサギでは $2.25 \pm 0.08$ $\mathrm{mg} / 48$ 時間であつた。そこして生後 50 日より測定したとてろ生後日数ととあにばんじ増量し，生後120日で成 照值に達した.

（2）尿中 $17-\mathrm{KS}$ 分劃は 8 分劃に分かれた. 生後50日より測定したところ, 各分劃とも日数ととあに増量 し，生後120日で成熟時の像に一致した。

（3）尿中 $17-\mathrm{OHCS}$ は，才ス成熟ウサギは $316 \pm 27.82 \gamma / 24$ 時間，メス成熟ウサギは292.8土33.94 / 24 時間 であつた，生後50日より測定したところ，生後日数とともに増加し，生後120日で成熟時の值に達した。

（4）尿中ウロペプシンは，凝乳能法ではオ久成熟りサギ $0.90 \pm 0.27 \mathrm{mg} / 24$ 時間， メ久成熟ウサギ 0.96 土

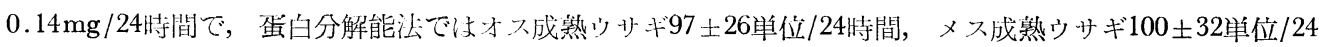
壯間であつた。いずれも生後50日より生後日数とともに增加し，生後120〜130日で成熟時の值に達した。

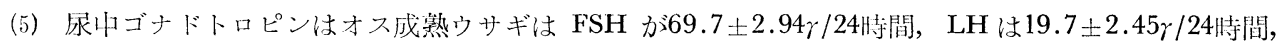




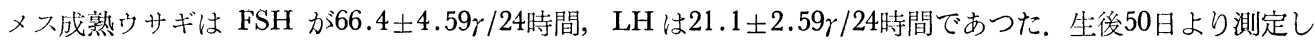
たところ，生後日数とともに増加してゆき，生後120日で成熟時の值に達した。

B 歴代甲状腺末投与子孫ウサギ $\left(\mathrm{F}_{1}, \mathrm{~F}_{4}, \mathrm{~F}_{5}, \mathrm{~F}_{6}\right)$ の成績

（1）尿中 17-KS 総量は $\mathrm{F}_{1}, \mathrm{~F}_{4}, \mathrm{~F}_{5}, \mathrm{~F}_{6}$ いずれす雌雄とすに対照より增量を示し, また累代的に増加して ゆき, $\mathrm{F}_{6}$ は対照の1.7倍の值を示した。

（2）尿中 17-KS 分劃は各代とむVI，VII分劃は対照より增加し，また累代的に増量し， $\mathrm{F}_{6}$ では刘照の約 3 倍の值を示した。

（3）尿中 17-OHCS は各代いずれも対照より増加し，また累代増量を示し， $\mathrm{F}_{6}$ は刘照の約2.5倍の増量を 示した.

（4）尿中ウロペプシンは凝乳能，蛋白分解能のいずれ屯累代增量し， $F_{6}$ は対照の約 20 倍の高值を示した.

（5）尿中ゴナドトロピンは各代とも FSH，LH いずれあ刘照より増加し，また累代的に増量し， $\mathrm{F}_{6}$ は対 照の約 3 倍の高值を示した。

(6) $\mathrm{F}_{5} ， \mathrm{~F}_{6}$ について生後50日より測定したととろ，上記各ステロイド，ウロペプシン，ゴナドトロピンの 增量は幼若時よりみと邓られ, 成熟時までその程度を増強しその後む常に刘照より増加した値を示した。 し か屯, $\mathrm{F}_{6}$ は常に $\mathrm{F}_{5}$ より増量の程度が強かつた。

G 甲状腺末投与ウサギの成績

甲状腺末投与後 30 日までは尿中 17-KS 総量, そのIII, VI, UII分劃, 17-OHCS, ウロペプシン, ゴナドト ロピンが増加するが，以後は次第に減少してりき，90日後ではいずれあ対照より若干低い值を示した。すす わち, 甲状腺末投与らサギは上述の先天性に甲状腺機能儿進像を示すウサギとは, 副腎皮質機能および尿中 ゴナドトロピンの態度に相違がみられる。

D 歴代甲状腺摘出子孫ウサギでは, 尿中 17-KS 総量, そのVI, III分劃, 17-OHCS, ウロペプシン, ゴ ナドトロピンはいずれも対照より減少し，しかも累代的に減少の傾向を示し， $F_{4}$ では尿中 17-KS 総量, 17-KS のVI，VII分劃，17-OHCS，ウロペプシンはそれぞれ刘照の 4/5，1/2，1/2，1/3 の值を示した．尿中 ゴナドトロピンは対照よりやや低い值を示した。

$\mathrm{E}$ 甲状腺摘出ウサギの成績

甲状腺摘出直後は尿中 17-KS，17-OHCS，ウロペプシン，ゴナドトロピンは若干增加するあのああるが， その後は緩慢に減少してゆき，90日後では尿中 17-KS 総量，17-OHCS，ウロペプシンはそれぞれ刘照の 3/5，1/3，1/4 の值を示した。 とくに 17-KS のII, III, VI, III分劃が著明に減少し， II， III分劃， VI, VII 分劃はそれぞれ対照の $1 / 3,1 / 5$ 以下の值を示し，尿中ゴナドトロピンも対照より著しく低い值 $(1 / 6)$ を示 した．乙の後の 2 点が歷代甲状腺摘出子孫ウサギと相違する。

本論文の要旨は第47回日本病理学会総会, 第31回日本内分泌学会総会に扣いて発表した。 尿中 17-KS, ウロペプシン澌定について御協力を得た教室赤沢好温博士に感謝する。

\section{文献}

1）赤沢好温：正常ならびに実験的先天性糖尿病ウサギの尿中 17-Ketosteroids 総量ならびに分割，17-Hydroxycorticosteroids, ウロペプシンについて，日内分泌誌，掲載予定２２）Anson，M.L. \& Mirsky, A.B.： The estimation of pepsin with hemoglobin, J. Gener., Physiol., 16, 59 63, $1933 . \quad 3$ 3) Bartels, E. D. : Heredity in Graves' disease, Munksgaard, Copenhague, $1941 . \quad 4)$ Bernheim, M., Berger, M. \& Uzan, R. : La rôle des facturs génétique dans le dévelopment du myxoedeme congenital, Comp. Ren. Soc. Biol., 149, 1553 1558, $1955 . \quad$ 5) Beierwaltes, W.H. \& Bishop, R.C. : 17-Ketosteroids and pituitary follicle stimulating hormone excretion in myxedema, before and during treatment with throxine, J. Clinic. Endocr., 14, 928 938, $1954 . \quad 6)$ Bradbury, J.T., Brown, E.S. \& Brown, W.E. : Adsor- 
btion of urinary gonadotrophins on kaolin, Proc. Soc. Exper. Biol. Med., 71, 228 232, 1949.

Bush, I.E. : Species difference in adrenocortical secretion, J. Endocr., 9, 95 100, 1953.

8) Bush,

I.E. : Recent work on the secretion of tne adrenal cortex, Schweitz. Med. Wschr., 85, 645 648, 1955.

9) Crooke, A.C. \& Butt, W.R. : Chemical assay of gonadotrophin in urine, The Lancet, 266, 379 383, 1954. 10) Drekter, I.J., Pearson, S., Bartezak, E. \& Mcgavak, T.H. : A rapid method for determination of total urinary 17-Ketosteroids, J. Clinic. Endocr., 7, 795 800, 1947.

11) Edwards, R.W.H. :

The determination of adrenocortical steroids and their metabolites, 53, Dennis Dobson, London, 1954.

12) Engstrom, W.W. \& Manson, H.L. : The excretion of 17-KS in patients with hyperthyroidism and myxedema, J. Clinic. Endocr., 4, 517〜527, 1944.

13）藤田栄一：甲状腺中毒症の副腎皮質機能に

関する研究，ホルモンと臨床，3，1448－1454，炤和30年.

14）福井定光：副腎皮質機能検査の実際，

日本臨床，14，328～338，昭和31年.

補遺，内科宝函，3，720～728，炤和31年.

15）福住一三，赤沢好温，川良一良：Uropepsin に関宁る知見

16）福田美恵子：外科侵襲よりみた視床下部一下垂体一 性腺系に関要る研究（前篇），日内分泌誌，33，464～489，炤和32年.

17) Gray, S. J., Ramsey, C., Reifenstein, R. W. \& Benson, J. A. : The significance of hormonal factors in the pathogenesis of peptic ulcer, Gastroenter., 25, 156 172, 1953.118$)$ Gray, S. J. \& Ramsey, C. : Adrenal influences upon stomach and gastric responses to stress, Recent Progr. Horm. Res., XIII, 583 617, Academic Press, New York, 1957.

19) Guinet, P., Bəthoux, R', Pommatau, E. \& Bertrand, J. : L' Hypergonadotrophinurie au cours de la Ménopause et de la castration, Ann. Endocr., 16, 800 804, 1955. Hechter, O. \& Pincus, G. : Genesis of the adrenocortical secretion, Physiol. Review, 34, 495 496, 1954. 21）日置陸奥夫：下垂体副腎系に関するシンポジウム，I，基礎と臨床，日内科誌，45，915～959，炤和 31 年. 22）日置陸奥夫：ホルモン化学検查法, 南江堂, 東京, 1956. 23)Howell, L.P., Drips, D.G. \& Fisher, H.C. : The presence of excesive amounts of gonadotrophic principle in the urine of patients with thyroid disease, Amer. J. Obst. Gyn., 41, 868 873, 1941.

24）入江一彦：歴代甲状腺摘出 雌雄ウサギより生まれた子孫ウサギ $\left(\mathrm{F}_{1} \sim \mathrm{F}_{3}\right)$ そ関する研究，東北医誌，55，357～381，昭和 32 年. 伊藤四十二：ホルモン検查法，脇同医書，東京，昭和31年. 26) 梶原和人：内分泌疾患の検查法，最 新医学，13，428４35，昭和32年. 27) Kass, E., Hechter，O., Macchi, I.A. \& Mou, T.W. : 8)上り引用. 28) Kenigsberg, S. \& Mc Gavak, T. H. : The excretion of 17-KS, II, Values in several endocrine disturbances, J. Glinic. Endocr., 12, 1551 1560, 1952.

29) Klinefelter, H.F., Albright, F. \& Griswold, G.C. :

Experience with quantitative test for normal or decreased amounts of follicle stimulating hormone in the urine in endocrinological diagnosis, J. Clinic. Endocr., 3, 529 544, 1943.

30) Krakaver, L.J., Ramsey, C.G. \& Gray, S.J. : Gastric activity and adrenocortical function, J. Clinic. Endocr., 17, 156 〜 176, 1957. 31) 倉持利夫：歴代甲状腺末投与雌雄ウサギより生まれた子孫ウサギ $\left(\mathrm{F}_{1} \sim \mathrm{F}_{3}\right)$ に関す る研究，東北医誌，55，357～381，昭和32年.

32) 栗本東一：甲状腺機能充進症と下垂体機能につい て，日内分泌誌，33，131，昭和32年. 33) 栗本東一：甲状腺機能六進症に打ける尿中性腺刺蛓ホル モンについて，日内分泌誌，34，226，昭和33年.

34) Levine, M.E. \& Daughaday, W.H. : The influence of the thyroid on the adrenocortical function, J. Clinic. Endocr., 15, 1499 1511, 1955. Masuda, M. : Urinary ketosteroids excretion patterns in congenital adrenal hyperplasia, J. Clinic. Endocr., 17, 1181 1190, 1957.

36) 松島早苗：尿中ゴナドトロピン定量法，No. 2，ホルモンと臨床， 3, 915 920, 炤和30年.

37) Mirsky, I.A., Block, S., Osher, S. \& Brohkahn, R.H. : Uropepsin excretion by man, 1 The source, properties and assay of uropepsin, J. Clinic. Invest., 27, 818 823, 1948.

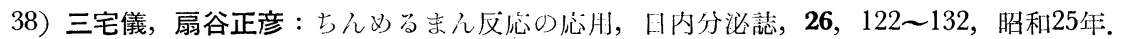
39) 三宅

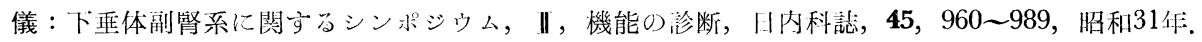
40)

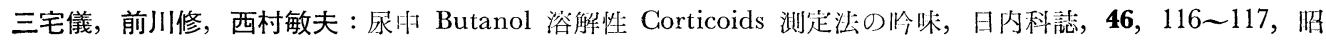


和32年. 41) 三宅儀：副腎皮質機能検査法批判，最䉼医学，15，1280～1287，炤和132年。

三宅儀：甲状腺腫とヨード代謝，日内分泌誌，34，514～525，昭和33年.

43) 三宅儀 : 家族的に多発 した峃純性甲状腺腫の症例，内科宝函，6，231～237，昭和34年.

44) 三宅有：用量作用曲線からみ た下垂体性，妊馬血清性，並びに妊婦尿性性腺刺戟ホルモンの相違について，塩野義研究所年報，6，142〜 151, 昭和31年. 45) 本橋賢二 : 数種内分泌疾患の尿中 Gonadotropin 排泄值について, 日内分泌誌, 33，346～353, 昭和32年. 46）中島養鄉：未発表. 47）中尾健, 中村悦郎, 大森義仁：脳下垂 体ホルモン，医学書院，東京，1957。 48) 岡本耕造 : 糖尿病の奏験的研究, 日病理会誌, 41 (総会号), 27〜43，1952. 49）岡本耕造, 福留金一郎：4 代または 5 代糖尿病を発症をした睢雄ウサギより生ま れたウサギ $\left(\mathrm{F}_{4}, \mathrm{~F}_{5}\right.$ ウサギ）に打ける糖尿病の自然発症について，日病理会誌，43 (総会号)，187〜 192， 昭和29年. 50) Okamoto, K. : Experimental pathology of diabetes mellitus, (Report II) III Studies on rabbits from ancestors diabetic for several successive generations, especially on spontaneous occurrence of diabetes in $\mathrm{F}_{4}$ and $\mathrm{F}_{5}$ rabbits, Tohoku J. Exper. Med., 61, Suppl. III, 62 112, $1955 . \quad$ 51) 岡本耕造 : 実験的糖尿病の子孫に及ぼす影響, 日内分泌誌，34，824〜845, 昭和33年. 52) 大橋敏郎, 東条伸平: 尿中 Gonadotrophin 定量法, 日独医報，3，3，1２3，炤和34年. 53) 大野文俊: 17-KS 亿関する臨床的知見補遺，日内分泌誌，31，337～367，昭和31年. 54) Pearson, S. \& Glacone, S. : A rapid modification of the Zimmermann test for ketosteroids, J. Clinic. Endocr., 8, 618 619, 1948. 55) Pincus, C. \& Pearlman, W.H. : Fractionation of neutral urinary steroids, Endocr., 29, 413 424, 1941. 56) Pond, $\mathrm{M} . \mathrm{H}^{\cdot}:$ A microchromatographic method for the separation of certain fractions of $17-\mathrm{KS}$ in human urine, The Lancet, 261, 906 909, 1951. $\quad 57)$ Porter, C. C. \& Silber, R. H. : A qualitative colour reaction for cortisone and related 17,21-dihydroxy-20-Ketosteroids, J. Biol. Chem., 185, 201 207, 1950. 58) Reddy, W. J., Jenkins, D. \& Thorn, G. W. : Estimation of 17-hydroxycorticoids in urine, Metabolism, 1, 511 527, $1952 . \quad 59)$ Reif, A. E. \& Longwell, B. B. : Extraction of corticosteroids from adrenal vein blood of rats and rabbits, Endocr., 62, 573 586, 1958.6 60) Rimington, C. : Seromucoids and bound carbohydrate of the serumproteins, Biochem. J., 34, 931 940, 1940. 61) Sadowski, L.F., Samnazzari, P. \& Zinolli, L. : Il compotamento della gonadostimolinuria nell' ipertiroidismo, Arch. E. Mal. Di. Pat. Glinic., 13, 1801 1806, 1957.

62）鎮目和夫：甲状腺疾患に於ける 他の内分泌機能について，綜合臨床，5，955９61，1956. $\quad 63)$ Smith，R.W., Mellinger, R. C. \& Patti G.W. : Modifications of the Reddy procedure for 17-hydroxycorticoids in urine, J. Clinic. Endocr., 14, 336 338, 1954. $\quad 64)$ Statland, H. \& Lerman, J.: Function of the adrenal cortex in myxedema with some observations on pituitary function, J. Clinic. Endocr., 10, 1401 1416, $1950 . \quad 65)$ 菅 原豊次, 村木忠雄：諸種疾患殊に内分泌疾患患者の尿中 17-KS について，ホルモンと臨床，5，465４70， 昭和32年. 66) 鈴木幸三 : 尿中 17-Ketosteroid 分劃之副腎皮質, 日内分泌誌，34，768～793，昭和 33年. 67) 鈴木昭三: 正常ならびに歴代糖尿病子孫ウサギとくに $F_{4}$ ウザの尿中 17-Ketosteroids に ついて, 東北医誌, 55, 463 489, 昭和 32 年. $\quad 68$ ) Swingle, S. M. \& Tiselius, A. : Tricalcium phosphate as an adsorbent in the chromatography of proteins, Biochem. J., 48, 171 178, 1951. Thimann, K. V. : Chemistry of anterior pituitary hormones, The Hormones, Vol. 1, 631 693, Academic Press, New York, 1948. 70）鳥居敏夫：甲状腺咨患に於ける副腎皮質機能，日内分泌誌， 25，228～ 229, 昭和34年. 71) Vartio， T. : Uropepsin excretion in neurocirculatory asthenia and thyrotoxicosis, Ann. Med. Exp. Biol. Fem., 34, 254 258, 1956. 72) 脇坂行一：甲状腺の臨床，日内科誌， 46, 1262 1295, 1958. 73) West, Ph. M., Ellis, F.W. \& Scott, B.L. : A simplified method for determining the excretion rate of uropepsin, J. Lab. Clinic. Med., 39, 159 162, $1952 . \quad 74)$ 山本清 : 内分泌機能の協関一甲状腺を中心として一，脇同医書，東京，昭和31年. 75）山崎高明：正常ならび に歴代雌雄甲状腺機能異常ウサギより生まれた子孫ウサギ $\left(\mathrm{F}_{1}, \mathrm{~F}_{4}, \mathrm{~F}_{5}, \mathrm{~F}_{6}\right)$ の甲状腺機能について, 日内分 泌誌，揭載予定. $\quad 76)$ Zimmermann, W. : Eine Farbreaktion der Sexualhormone und ihre Anwendung zur quantitative colorimetrische Bestimmung, Z. Physiol. Chemie, 233, 257 264, $1935 . \quad 77$ ) Zimmermann, W. : Colorimetrische Bestimmung der Keimdrüsenhormone, Z. physiol. Chemie, 245, 47〜 57, 1936. 